\title{
Solid bitumen in shales from the Middle to Upper Jurassic Sargelu and Naokelekan Formations of northernmost Iraq: implication for reservoir characterization
}

\author{
Nagham Omar $^{1}$ (D) $\cdot$ Tom McCann $^{1} \cdot$ Ali I. Al-Juboury ${ }^{2} \cdot$ Isabel Suárez-Ruiz $^{3}$
}

Received: 25 December 2020 / Accepted: 29 March 2021 / Published online: 21 April 2021

(C) The Author(s) 2021

\begin{abstract}
Petrographic, organic, and inorganic geochemical analysis of the solid bitumen and host shales from the Middle and Late Jurassic-age Sargelu and Naokelekan Formations of the Banik section, northernmost Iraq, was undertaken. The aim was to understand their derivation and preservation, as well as examine the carbon and oxygen isotopes, and paleoredox proxies under which the solid bitumen and host sediments were deposited. Petrographic analysis of both formations revealed the presence of solid bitumen high reflectance (first phase) and solid bitumen low reflectance (second phase). The equivalent vitrinite reflectance indicates that the solid bitumen of the two formations probably accumulated within the shale reservoirs following oil migration from source rocks located within the same formations. Mineralogical study (XRD and SEM - EDX) revealed that the shales hosting the solid bitumen also contain clay minerals (illite, rectorite, chlorite, montmorillonite, and kaolinite) as well as carbonate minerals, quartz, alkali feldspar, and pyrite. Carbon and oxygen isotope data along with paleoredox indicators suggest that both the solid bitumen sources and host shales in both formations formed within a shallow-marine setting, most probably under anoxic conditions where water circulation was restricted.
\end{abstract}

Keywords Solid bitumen $\cdot$ Stable isotopes $\cdot$ Paleoredox $\cdot$ Migration $\cdot$ Shale $\cdot$ Jurassic $\cdot$ Iraq

\section{Introduction}

Iraq is the sixth largest oil reserve in the world (Al-Zubaidi and Al-Zebari 1998; Jassim and Al-Gailani 2006), with current proven reserves of 115 billion barrels of oil (BBO) and 110 trillion cubic feet (TCF) of gas. This hydrocarbon reserve presents in three petroleum systems, namely Palaeozoic, Jurassic, and Cretaceous-Tertiary (Fig. 1) (Ahlbrandt et al. 2000; Verma et al. 2004). Most of the petroleum that has been

Responsible Editor: Domenico M. Doronzo

Nagham Omar

s6naomar@uni-bonn.de

1 Institut für Geowissenschaften - Geologie, University of Bonn, Nussallee 8, 53115 Bonn, Germany

2 Geology Department, College of Sciences, University of Mosul, Mosul, Iraq

3 Instituto de Ciencia y Tecnología del Carbono (INCAR-CSIC), Oviedo, Spain discovered in Iraq is reported to have been sourced from the Jurassic-age rocks and trapped in the Cretaceous- and Tertiary-age reservoirs of the Mesopotamian Basin and the Zagros Basin/Zagros Fold Belt (Pitman et al. 2004) (Fig. 1).

The study area is situated within the Kurdistan Region of Iraq which is estimated to contain about $39 \%$ of Iraq's total barrels of oil reserves. Recent studies have indicated that most of the discovered oil in the Kurdistan Region of Iraq was sourced from the Sargelu (Middle Jurassic), Naokelekan (Upper Jurassic), and Chia Gara (Late Jurassic-Early Cretaceous) Formations (Al-Ameri and Zumberge 2012; Mohialdeen et al. 2013; Tobia et al. 2019).

Because of the geological and economic importance of the Jurassic successions in Iraq, they have been described in numerous studies, the majority of which have focused on the lithology and depositional environments of the successions and their economic significance (e.g., Daoud and Karim 2010; Al-Ameri and Zumberge 2012; Al-Juboury and McCann 2013; Jasim 2013; Abdula 2017).

The Middle Jurassic-age Sargelu Formation was first described by Wetzel (1948) from the Surdash Anticline in the High Folded Zone, NE of Iraq (Bellen et al. 1959; Jassim and 


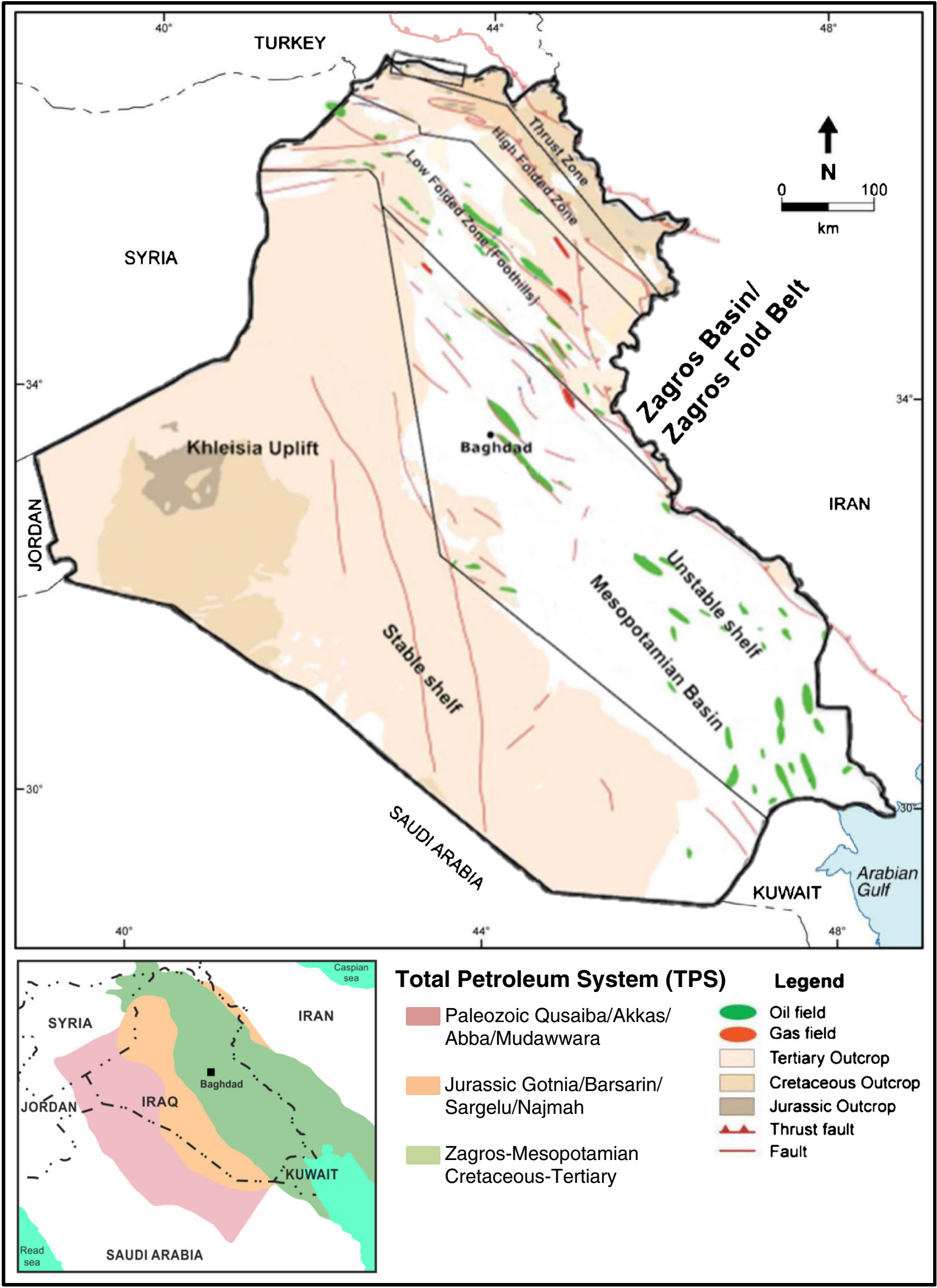


Fig. 1 Map showing major oil and gas fields in the regions of Mesopotamian Basin and Zagros Basin/Zagros Fold Belt (after Aqrawi 1998). Inset map depicts three total petroleum systems (TPS) that have contributed to the petroleum accumulations in Iraq (Ahlbrandt et al. 2000)

Goff 2006). Subsequently, the formation was correlated with successions in Iran (James and Wynd 1965), Turkey, and Syria (Altinli 1966; Dubertret 1966). On the contrary, the Late Jurassic-age Naokelekan Formation was first described by Wetzel and Morton (1950) from the Balambo-Tanjero Zone near Rowanduz.

The redox-sensitive trace metals have been used widely as geochemical proxies to determine the redox status of marine sediments at the time of their deposition as well as their provenance (Ramos-Vázquez and Armstrong-Altrin 2019; Bennett and Canfield 2020), and thus provide direct information on the depositional environment. Similarly, the carbon isotope geochemistry is used as a good indicator of the depositional setting waters (Bowman and Bralower 2005; Jarvis et al. 2006). On the other hand, the oxygen isotope geochemistry is considered to be an important indicator of the dominated climate conditions during the period of deposition (Bartolini et al. 2003; Ruf et al. 2005; Weissert and Erba 2004).

Future work on the organic geochemistry of the Sargelu and Naokelekan Formations has been published (Al-Ahmed 2006; Aqrawi and Badics 2015; El Diasty et al. 2018; Abdula et al. 2020). However, detailed studies of the solid bitumen from these two Jurassic-age formations were not, to date, attempted. Bellen et al. (1959) studied the presence of solid bitumens in the Naokelekan Formation, but misinterpreted them as coal horizons. To fulfill this gap, in this study, we examined the detailed petrographic, organic, and inorganic geochemistry of the solid bitumen as well as the host shales of the Sargelu and Naokelekan Formations from the Banik section in northernmost Iraq, including the carbon and oxygen isotopes and paleoredox proxies. Therefore, the objectives of this study are to (1) suggest possible depositional environment of the solid bitumen and host sediments provided by the carbon and oxygen isotopes, and paleoredox proxies, and (2) reconstruct the accumulation process for the solid bitumen present within the formations and decipher its origin by integrating the geochemical data with the equivalent vitrinite reflectance.

\section{Geological setting}

The study area is situated within the region of northernmost Iraqi Kurdistan within the Zagros Basin/Zagros Fold Belt on the northeastern boundary of the Arabian Plate (Abdula 2017; Liu et al. 2018). The Zagros Basin is one of the most hydrocarbonrich basins in the world (Sarfi et al. 2015) with these being mainly sourced from Jurassic marine carbonates (Al-Ahmed
2006). Middle to Upper Jurassic Sargelu and Naokelekan Formations in Iraq are organic rich and comprise intercalated shallow-marine carbonates and highly porous and permeable shales/sandstones forming the main reservoir unit (Murris 1980; Beydoun 1991; Sharland et al. 2001). The two formations are subsequently overlain by a seal of evaporites forming a closed petroleum system. The lateral extent of these formations, and related units, from Iraq to Saudi Arabia and the Gulf States is the reason for the hydrocarbon-rich productivity across the region (Murris 1980; Beydoun 1991; Sharland et al. 2001).

The Banik section is located near the boundary between the High Folded Zone and the Thrust Zone (i.e., the Northern (Ora) Thrust Subzone) (Fig. 2a). The Sargelu and Naokelekan Formations crop out in Northern Iraq within the eroded cores and limbs of anticlines in structural zones of the Zagros Basin/ Zagros Fold Belt area (Numan 2000). These zones include, from SW to NE, the Low Folded Zone (or Foothills), the High Folded Zone, and the Imbricated Zone (Fig. 2a) (Jassim and Goff 2006). According to Zainy et al. (2017), the Imbricated Zone can be further subdivided into two zones, namely the Balambo-Tanjero Subzone and the Northern (Ora) Thrust Subzone. This latter subzone is approximately $15 \mathrm{~km}$ wide and trends E-W in the border area of Northern Iraq and Turkey (Balaky et al. 2016; Edilbi et al. 2017; Zainy et al. 2017).

The thickness of the Sargelu Formation varies from 74 to $447 \mathrm{~m}$ (Jassim and Buday 2006). In its type section, the Sargelu Formation is about $115 \mathrm{~m}$ thick, and consists of bituminous dolomitic limestones and black shales with thin chert towards the tops (Wetzel 1948; Jassim and Buday 2006). In the subsurface, higher proportions of shale as well as rare fine-grained sandstones have also been noted (Jassim and Buday 2006).

The age of the Sargelu Formation has been determined based on the presence of the pelecypods (e.g., Bositra buchii), and is considered to be Bajocian-Bathonian (Bellen et al. 1959; Jassim and Goff 2006). In addition to the presence of the pelecypods in the Sargelu Formation, gastropods, radiolaria, ostracods, calcispheres, and algal filaments (e.g., Abdula et al. 2015) have been recorded within the same formation in some areas of Northern Iraq.

Al-Ameri et al. (2012) suggested a Bajocian-Bathonian, and possibly Lower Callovian, age based on palynomorph index. Thus, while a Middle Jurassic age for the Sargelu Formation has been confirmed, there is still a lack of precision with regard to the age boundaries. The contact between the Sargelu Formation and the underlying Sehkaniyan Formation in the type area is usually conformable and gradational (Bellen et al. 1959; Jassim and Goff 2006).

In the subsurface, the boundary is defined by the final occurrence of anhydrite (Jassim and Buday 2006). The contact with the overlying Naokelekan Formation appears to be conformable and gradational (Bellen et al. 1959; Jassim and Goff 2006). The Sargelu Formation was deposited in a basinal euxinic marine environment (Bellen et al. 1959; Jassim and Goff 2006). 
Fig. 2 (a) Geological map of Northern Iraq showing the study area and the structural zones of the Zagros Basin/Zagros Fold Belt (after Awdal et al. 2016). (b) Geological map of northernmost Iraq including Banik section and the two formations (Sargelu and Naokelekan) (after Al-Mousawi et al. 2008)
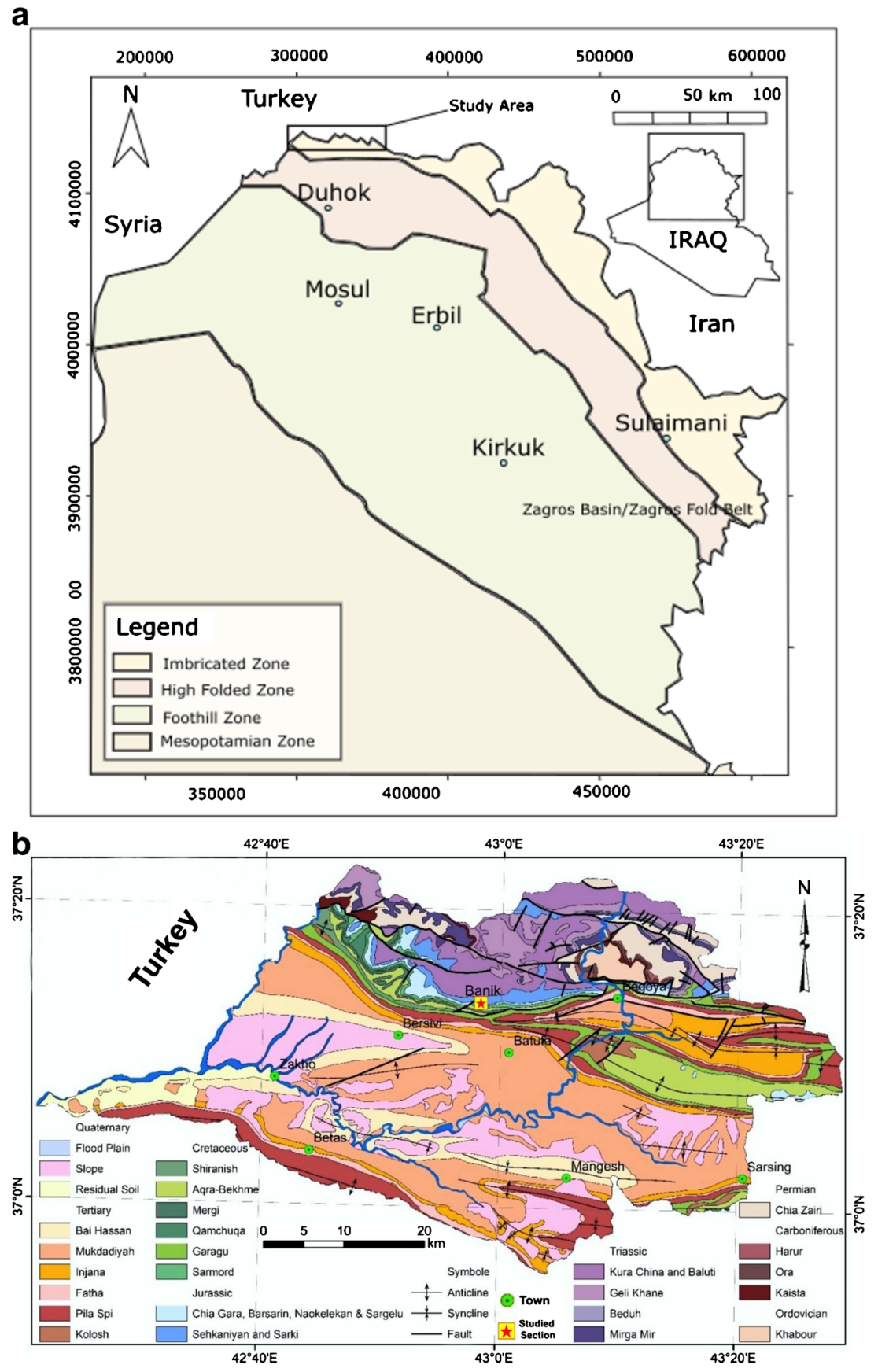

The type section of the overlying Naokelekan Formation comprises $20 \mathrm{~m}$ and can be subdivided into three units (Wetzel and Morton 1950). From base to top, these are as follows: (a) thinly bedded, bituminous limestones with intercalated bituminous black shales and limestones, (b) thinly bedded, fossiliferous dolomitic limestones, and (c) thinly bedded, highly bituminous dolomites and limestones interbedded with black shales in the lower part (Jassim and Buday 2006). An Early Callovian-Kimmeridgian age was proposed for the Naokelekan Formation based on the recorded fauna, including belemnites, stromatoporoids, foraminifera, and algae (Jassim and Buday 2006).
The lower and upper contacts of the formation with the Sargelu and Barsarin Formations, respectively, appear to be conformable (Bellen et al. 1959; Jassim and Goff 2006). However, the recognition of the lower contact in northernmost Iraq is difficult although it is generally assumed to be gradational (Buday 1980). The lack of chert and the presence of abundant Posidonia and other ammonites distinguish the Sargelu Formation from the Naokelekan Formation (Wetzel 1948). Additionally, the latter contains solid bitumen (Wetzel 1948), although solid bitumen was also recorded from the Sargelu Formation as part of this study. The sediments of the Naokelekan Formation were deposited in an euxinic 
environment, in a subsiding, or possibly starved, basin (Bellen et al. 1959; Jassim and Goff 2006).

The current study focused on the solid bitumen present within the host shale successions of the Sargelu and Naokelekan Formations of the Banik section (Fig. 2b). This section crops out in a region where access is now forbidden. Thus, due to recent political upheavals, this work will remain unique for the foreseeable future. The sedimentary succession from the Banik section comprises interbedded shales and carbonates (dolomites, limestones) and is considered to be of great importance given its singularity in northernmost Iraq, as well as the fact that it is the only location from which solid bitumen from the Sargelu Formation has been recorded. As noted above, the studied shale beds hosting the bitumen, particularly those from the Naokelekan Formation in the Banik area, were originally misinterpreted by Bellen et al. (1959) who described them as a 4-m-thick coal horizon, while those from the Sargelu Formation, i.e., the shale beds hosting bitumen, were recorded for the first time as part of this study. A detailed sedimentary log is shown in Fig. 3.

\section{Materials and methods}

A total of eight shale samples hosting bitumen (four from the Sargelu Formation and four from the Naokelekan Formation) were collected from the Banik section. The samples were collected for detailed petrographic, mineralogy, organic, and inorganic (trace and carbon and oxygen stable isotopic geochemistry) analyses.

Petrographic investigation of the solid bitumen was conducted using optical microscopy at the Instituto de Ciencia y Tecnología del Carbono (INCAR-CSIC) Oviedo, Spain. Organic petrography characterization was carried out on all the samples using reflected white light and blue light excitation (fluorescence mode). These analyses were mainly focused on the identification of the organic populations present in the samples, their characterization, and the reflectance measurement in the case of solid bitumen. The optical microscopy measurements were performed on particulate pellets (whole rock) with randomly orientated particles using a MPV-Combi (Leitz) microscope, reflected light, and $\times 50$ oil immersion objectives following the ASTM D 2798-09 (2010) and ISO $7404 / 5$ (2009) norms. The pellets were prepared following a modified procedure of the ISO 7404/02 (2009) standard that does not employ a press and temperature. Fluorescence, white light observations, and optical photomicrographs were taken on a DM 4500P Leica microscope using a DFC 420C Leica camera with the corresponding software to capture and analyze the images.

The solid bitumen and host shale samples from both the Sargelu and Naokelekan Formations were examined using Cambridge S 200 Stereoscan (Cambridge, UK) and a LEO
1450 (Cambridge, UK) scanning electron microscopes, which were used for imaging, and energy dispersive X-ray (EDX) analyses. These were equipped with secondary electron (SE) and backscattered electron (BSE) detectors and an EDX analysis system (Oxford Instruments, Oxford, UK) using the Link ISIS Software at the Nees Institute Laboratory, Bonn University.

The mineralogical constituents of the host shales were determined using the XRD. Sampling material for XRD measurements was analyzed as powder preparation in a D8 Advance from the company Bruker AXS GmbH and the acquired data was analyzed using the software MacDiff 4.2.6 and Rietveld method.

The total organic carbon (TOC) measurement of the solid bitumen and host shale samples was conducted using a Vario EL cube from the company Elementar Analysensysteme GmbH.

Furthermore, stable isotopic data for carbon and oxygen were conducted at the Ruhr-Universität Bochum, with a mass spectrometer MAT253 (Thermo Fisher Scientific) equipped with a ConFlo IV and a GasBench II (both Thermo Fisher Scientific), while the inorganic trace elements of the same samples were analyzed (XRF) in the Institut für Geowissenschaften-Geologie, Bonn University. Measurements were performed with an AXIOS from the company PANalytical GmbH.

\section{Results}

\section{Organic petrography}

Petrographic analysis of the samples collected from the shale beds hosting the bitumen from the Sargelu and Naokelekan Formations revealed that the host shale is rich in solid bitumen which is interbedded with mineral matter (Fig. 4a, b). Two bitumen phases were recognized: solid bitumen with high reflectance and solid bitumen with low reflectance (Table 1). The bitumen with high reflectance can be classified as Grahamite, while the bitumen with low reflectance would correspond to a Glance Pitch (Jacob 1989). In general, the solid bitumen with high reflectance is dominant as seen by the number of nitrogen measurements (48-180) with the exception for samples 3 and 4 from the Sargelu Formation which have values of c. 25 and 32 (Table 1). The solid bitumen samples were also analyzed under a microscope for their fluorescence, as well as using UV excitation. There was no evidence of any fluorescence.

\section{Mineralogy}

The mineralogy of the solid bitumen and host shales from the Sargelu and Naokelekan Formations was carried out by means of X-ray diffraction (XRD) and SEM - EDX analysis. 
a

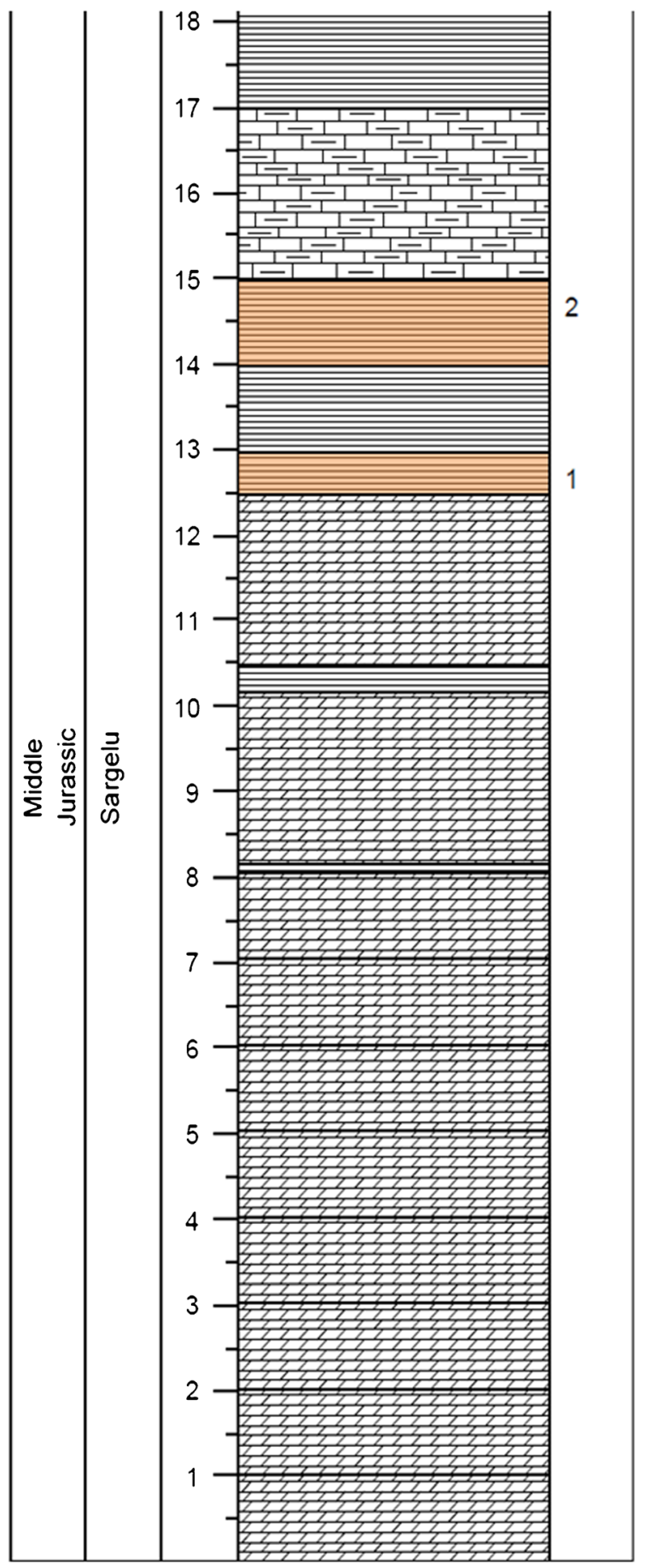

b

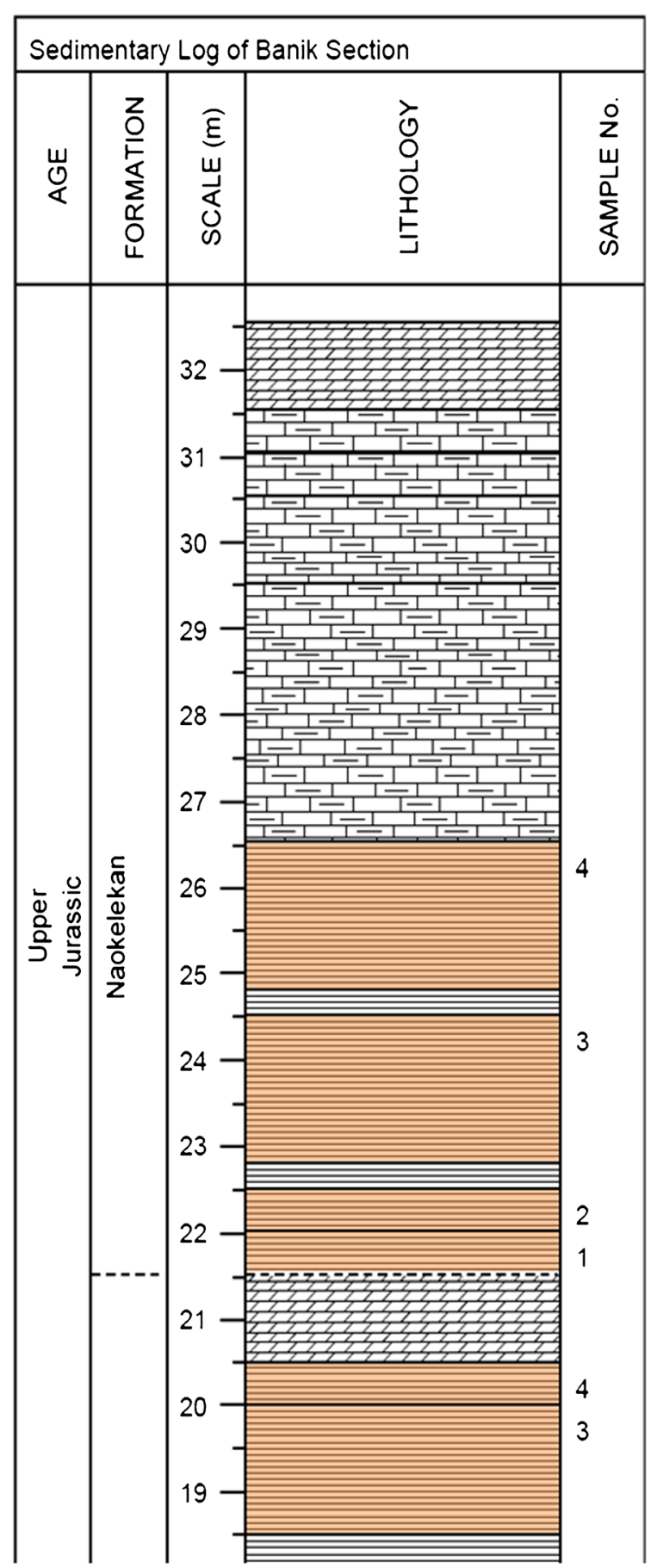

Base Boundaries

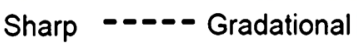

Lithologies
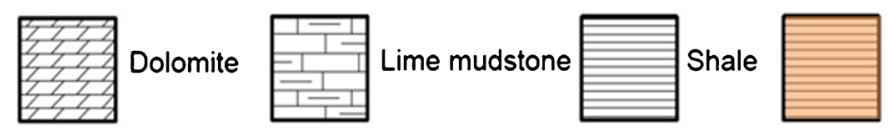

Shale hosting solid bitumen

Fig. 3 Lithological section of the studied formations at Banik area of northernmost Iraq with sample locations 

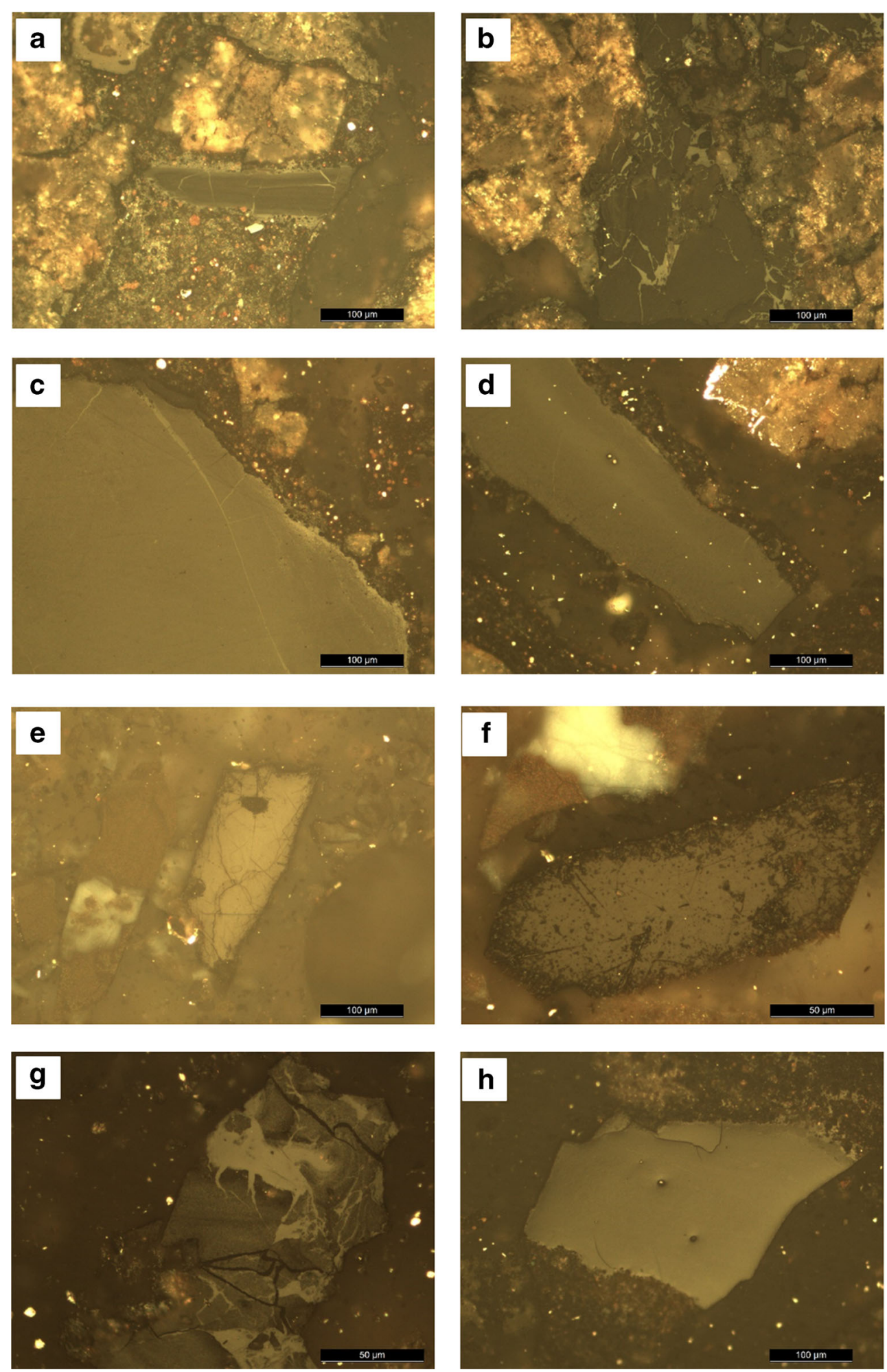

Fig. 4 (a) Optical microscopy (reflected white light) photomicrographs of the Sargelu Formation. (a)-(h) Grahamite (light chrysolite color), glance pitch (dark chrysolite color), scattered crystals of mineral matter (shiny color). (b) Optical microscopy (reflected white light) photomicrographs

of the Naokelekan Formation. (a), (b) Grahamite (light green color), glance pitch (dark green color), scattered crystals of mineral matter (shiny color). (c)-(h) Grahamite (light chrysolite color), glance pitch (dark chrysolite color), scattered crystals of mineral matter (shiny color) 

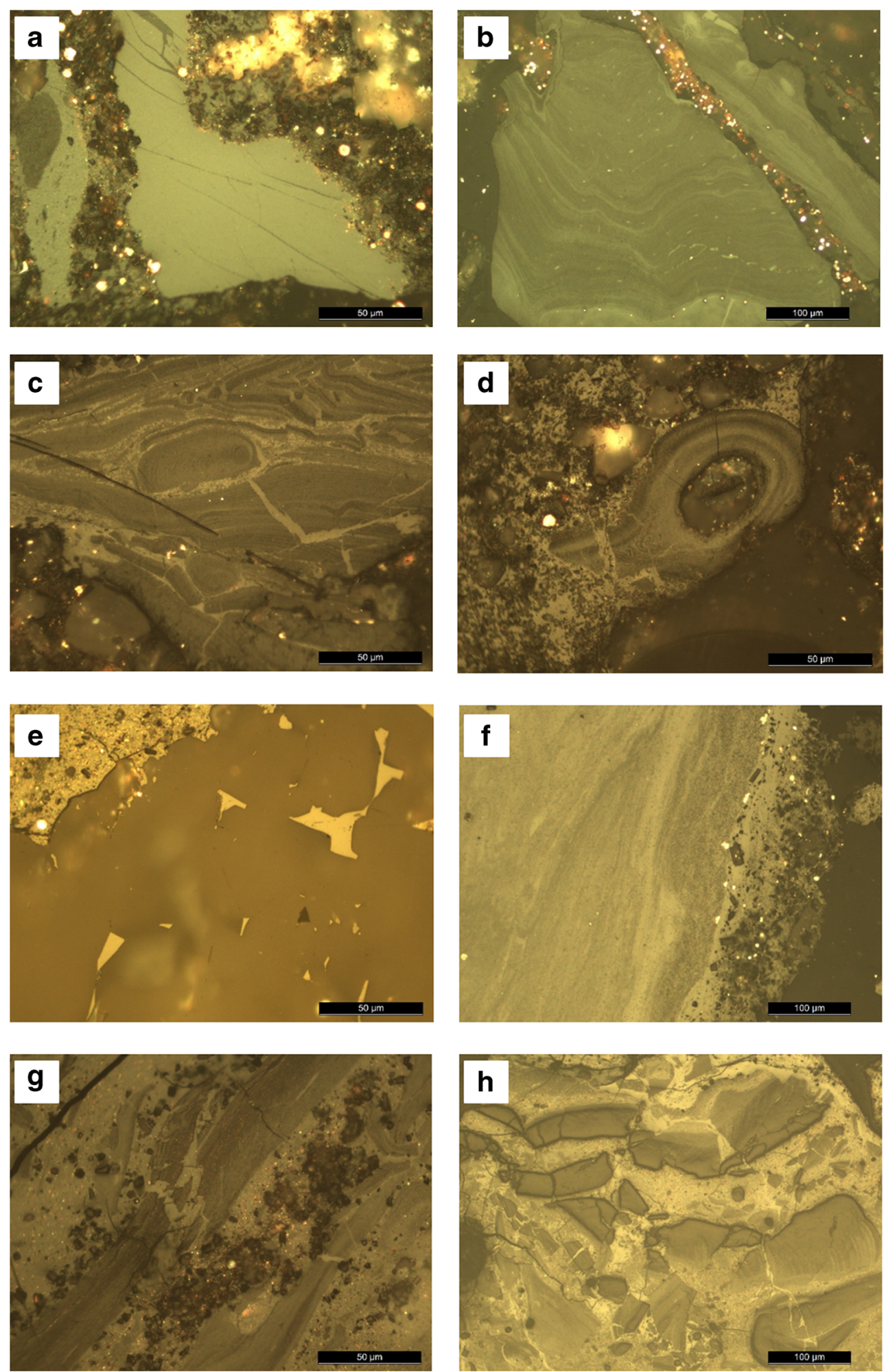

Fig. 4 (continued)

XRD analysis showed the following results averaged for minerals in the studied samples (Fig. 5a, b; Table 2). Likewise, Akkoca and Ișık (2018) found these minerals in Dadaș shales, rich in organic matter, in southeastern Turkey.
Based on these results, it is concluded that the two formations differ in terms of their mineralogical compositions. The SEM and EDX analyses confirmed the presence of illite in the Naokelekan Formation (Fig. 6h; 
Table 1 Solid bitumen reflectance values identified in the shale reservoirs from the Sargelu $(\mathrm{S})$ and Naokelekan $(\mathrm{N})$ Formations

\begin{tabular}{|c|c|c|c|c|c|c|c|}
\hline \multirow[b]{2}{*}{ Sample no. } & \multirow[b]{2}{*}{ Formation } & \multicolumn{3}{|c|}{ Solid bitumen first phase } & \multicolumn{3}{|c|}{ Solid bitumen second phase } \\
\hline & & Reflectance $(\%)$ & $\mathrm{S}$ & $\mathrm{N}$ & Reflectance (\%) & S & $\mathrm{N}$ \\
\hline 1 & Sargelu & 0.45 & 0.08 & 48 & 0.19 & 0.06 & 12 \\
\hline 2 & Sargelu & 0.54 & 0.07 & 109 & 0.27 & 0.05 & 50 \\
\hline 3 & Sargelu & 0.52 & 0.04 & 25 & 0.30 & 0.05 & 65 \\
\hline 4 & Sargelu & 0.66 & 0.06 & 32 & 0.38 & 0.08 & 68 \\
\hline 1 & Naokelekan & 0.59 & 0.06 & 102 & 0.34 & 0.05 & 23 \\
\hline 2 & Naokelekan & 0.54 & 0.04 & 69 & 0.36 & 0.07 & 31 \\
\hline 3 & Naokelekan & 0.54 & 0.05 & 180 & - & - & - \\
\hline 4 & Naokelekan & 0.51 & 0.04 & 177 & 0.27 & 0.06 & 23 \\
\hline
\end{tabular}

Supplementary Fig. 1y), as well as the presence of montmorillonite and chlorite (Fig. 6h; Supplementary Fig. 1w, $\mathrm{x}$ ), while rectorite (dioctahedral mica/montmorillonite) and kaolinite were observed from the underlying Sargelu Formation (Fig. 6d; Supplementary Fig. 1f, 1).

\section{Geochemistry}

\section{Organic geochemistry}

Total carbon, organic carbon, and total sulfur The organic carbon (TOC) content (Table 3) varies from 4.3 to $14.5 \%$ in the samples from the Sargelu Formation with a mean value of $9.15 \%$, while the total carbon (TC) content for the same samples ranges from 10.0 to $19.56 \%$ with a mean value of $15.34 \%$ (Table 3). In contrast, the samples from the Naokelekan Formation have the highest measured TOC contents (up to $48.1 \%$; Table 3 ) with a mean value of $29.43 \%$. The TC content for the same samples ranges from 24.73 to $48.9 \%$ with a mean value of $34.24 \%$ (Table 3).

The total sulfur (TS) content in the Sargelu Formation samples varies from 0.54 to $1.60 \%$, while the samples from the Naokelekan Formation have higher TS contents ranging from 2.06 to $5.44 \%$ (Table 4 ).

Carbon and oxygen isotopes Table 5 lists the carbon isotope $\left(\delta^{13} \mathrm{C}\right)$ and oxygen isotope $\left(\delta^{18} \mathrm{O}\right)$ values of the solid bitumen and host shale samples from the two formations. The $\delta^{13} \mathrm{C}$ values of the samples from the Sargelu Formation range from -2.58 to $-7.10 \%$, while the $\delta^{18} \mathrm{O}$ values from the same formation range from -3.75 to $-7.19 \%$. In contrast, the $\delta^{13} \mathrm{C}$ values of the samples from the Naokelekan Formation vary from -5.38 to $-6.60 \%$, while the $\delta^{18} \mathrm{O}$ values range from -6.34 to $-6.71 \%$ o. One sample (sample 4 ) from the latter formation did not contain any carbonate (or only trace amounts; Table 2) and so no values could be calculated.

\section{Inorganic geochemistry}

X-ray fluorescence (XRF) analysis was used to determine the trace element compositions of the two formations (Table 6). The solid bitumen and host shales of the Sargelu Formation have high amounts of $\mathrm{Ba}, \mathrm{V}, \mathrm{Mo}, \mathrm{Cu}, \mathrm{Zr}, \mathrm{W}, \mathrm{Zn}, \mathrm{Sr}, \mathrm{Cr}$, and $\mathrm{Rb}$. The $\mathrm{Ba}$ values for samples 1 and 2 from the Sargelu Formation are 104 and 113 ppm, which are higher than the values of samples 3 and 4 (22-82 ppm). The $\mathrm{V}$ value for sample 3 from the same formation is $130 \mathrm{ppm}$, which is lower than the general values of c. 300-500 ppm. The Mo value for sample 2 from the same formation is $662 \mathrm{ppm}$, which is higher than the general values of c. 100-275 ppm. The $\mathrm{Cu}$ values for samples 1 and 2 of the Sargelu Formation are 90 ppm and 134 ppm, which are higher than the values of samples 3 and 4 (15$60 \mathrm{ppm})$. The $\mathrm{Zr}$ value of $8 \mathrm{ppm}$ for sample 3 from the Sargelu Formation is lower than the general values of c. $37-54 \mathrm{ppm}$. The $\mathrm{W}$ value for sample 3 from the same formation is 144 $\mathrm{ppm}$, which is higher than the general values of c. $20-40 \mathrm{ppm}$. The $\mathrm{Zn}$ value for sample 4 from the same formation is $74 \mathrm{ppm}$, which is lower than the general range of values (c. 152-200 $\mathrm{ppm})$. The $\mathrm{Sr}$ values for samples 1 and 2 from the same formation are 81 and $98 \mathrm{ppm}$, which are lower than the values of samples 3 and 4 (c. 124-150 ppm). The Cr value for sample 3 from the same formation is $18 \mathrm{ppm}$, which is lower than the general values of c. 55-83 ppm. The Rb value for sample 3 from the same formation is $6 \mathrm{ppm}$, which is also lower than the general values of c. 21-38 ppm.

Samples from the Sargelu Formation also showed varied ranges for $\mathrm{Ni}(200-448 \mathrm{ppm}), \mathrm{Mn}$ (21-70 ppm), $\mathrm{Pb}$ (14-19 ppm), As (13-68 ppm), U (13-34 ppm), Ce (13-26 ppm), Y (11-36 ppm), Co (10-30 ppm), La (6-20 ppm), and Nd (5-16 ppm), while Th, Hf, Sm, Cs, Nb, Sc, and Ga have considerably lower ranges of 1-9 ppm (see Table 6).

The trace element distributions of the Naokelekan Formation are generally higher than those of the Sargelu Formation, for example, Ba (150-300 ppm), V (800-2000 


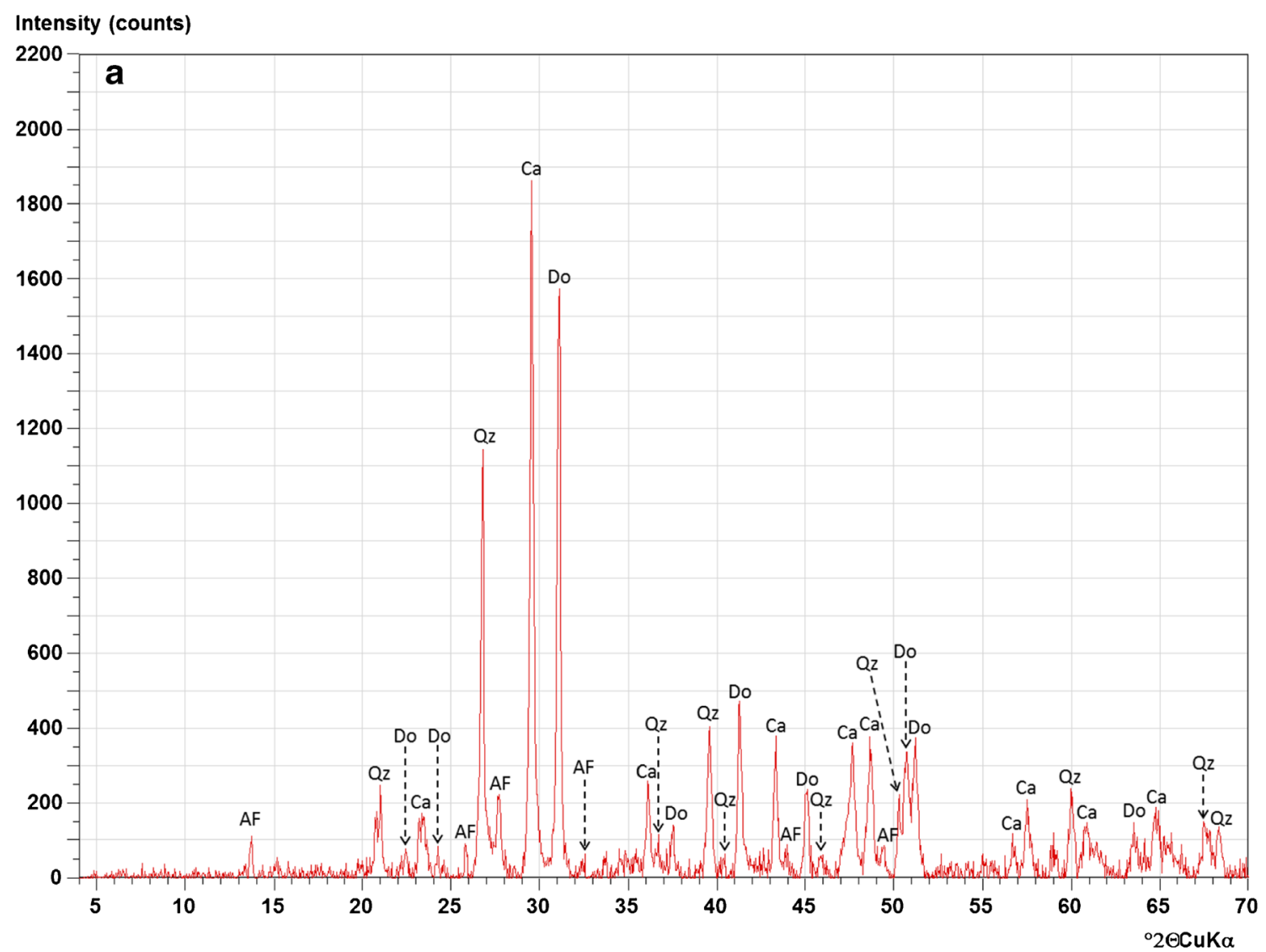

Intensity (counts)

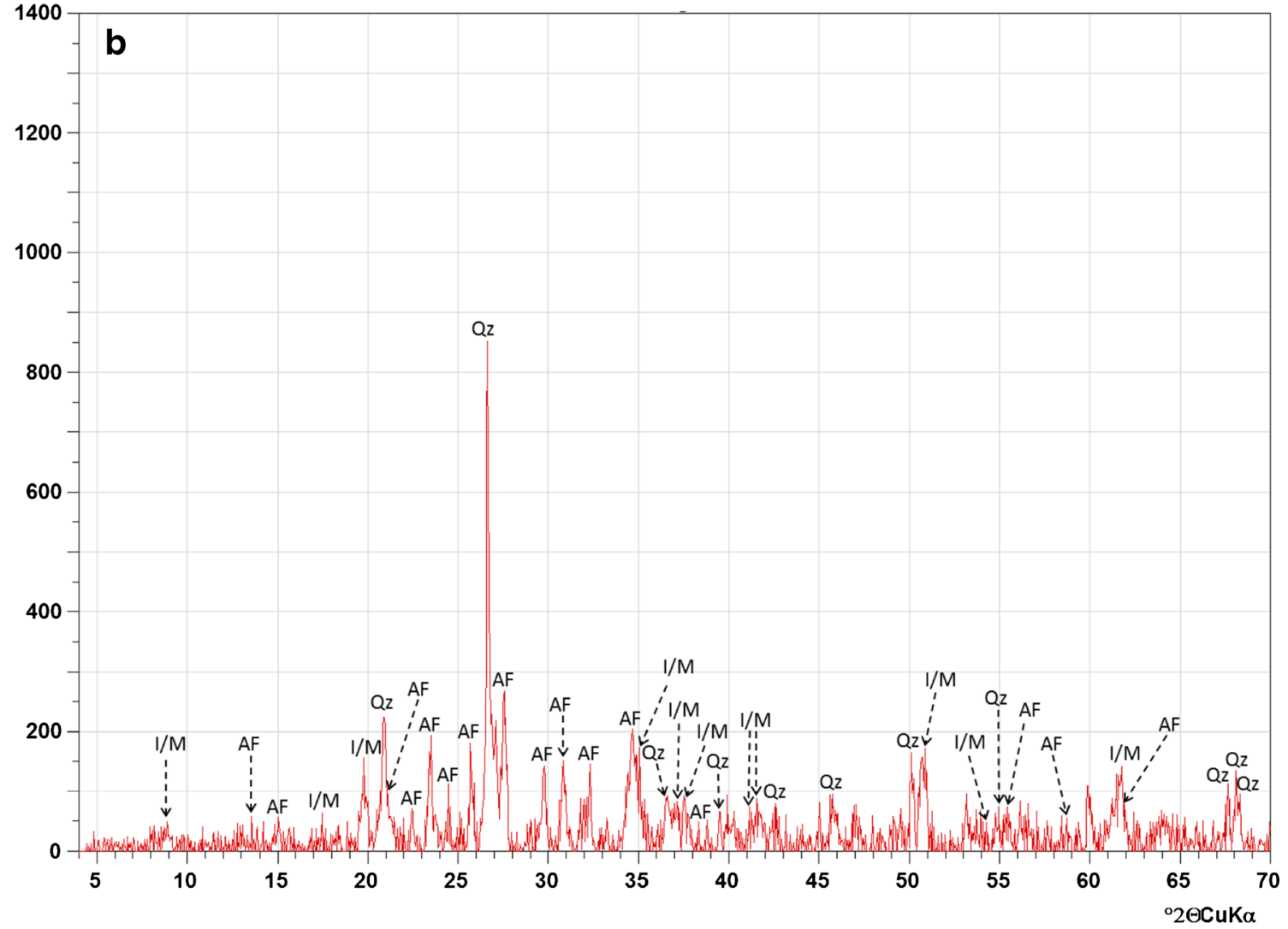


Fig. 5 X-ray diffractograms of selected samples from the Sargelu and Naokelekan Formations illustrating the clay and non-clay minerals in the host shales and solid bitumen. (a) Sample 4, Sargelu Formation. (b) Sample 4, Naokelekan Formation (see Fig. 3 for sample location)

ppm), Zn (200-1000 ppm), Cr (70-300 ppm), As (25-77 ppm), U (33-68 ppm), Y (26-85 ppm), and Nd (10-27 $\mathrm{ppm})$. The values for Mn (20-58 ppm) and Co (3-11 ppm), however, are slightly lower than those from the underlying Sargelu Formation. The Th, Hf, Sm, Cs, Nb, Sc, and Ga values are very low (i.e., $<1-9 \mathrm{ppm}$ ), and thus very similar to those from the underlying Sargelu Formation (see Table 6).

The general range of the trace element values is similar for both formations (Table 6).

\section{Discussion}

Petrographic, organic, and inorganic geochemical analyses were undertaken on 8 samples of solid bitumen and the corresponding host shales from the Middle and Late Jurassic-age Sargelu and Naokelekan Formations from the Banik section, northernmost Iraq. While the solid bitumen is a secondary organic product resulting from the transformation of oils generated from the organic matter of primary origin (mainly highly hydrogenated organic matter), the precise origin of the solid bitumen present within the formations is unclear although the vitrinite reflectance and mineral contents provide important information in this regard. The following discussion, will review, in detail, the main aspects of the analyses, commencing with those which provide direct information on the depositional environment (i.e., isotopes, paleoredox proxies) before examining the aspects which are of more local significance (i.e., vitrinite reflectance, mineral content).

\section{Carbon and oxygen isotope data}

The carbon isotope $\left(\delta^{13} \mathrm{C}\right)$ values of the solid bitumen and host shale samples from the Sargelu and Naokelekan
Formations are all negative. Negative values are generally considered to be indicative of marine regression, while positive values have been related to periods of marine transgression (Bowman and Bralower 2005; Jarvis et al. 2006). Thus, deposition of the solid bitumen and host shales from the Sargelu and Naokelekan Formations of northernmost Iraq probably occurred during a period of marine regression and the establishment of a shallow-water depositional setting.

According to Buday (1980) and Haq (2018), the deposition of the Middle to Upper Jurassic successions coincided with a broad eustatic transgression, resulting in higher global sea level (Hallam 1982; Alsharhan and Nairn 2003). Despite this eustatic rise, the carbon isotope values of the solid bitumen and host shale samples from the Middle and Late Jurassic-age Sargelu and Naokelekan Formations are interpreted as having been deposited in a shallow-marine setting. This disparity in terms of the rising eustatic sea level versus the shallow-marine setting in the area of Northern Iraq requires an explanation. Given that the region is located within the Zagros Basin/ Zagros Fold Belt, an area which was tectonically active, it is possible that regional deformation due to Cimmerian-related uplift (Buday 1980) would have negated, or modified, the eustatic sea level rise.

Analysis of the oxygen isotope values from the solid bitumen and host shale samples from the formations also shows negative values, indicative of warmer waters. Thus, deposition of the formations correlates well with the suggested Jurassic climate being dominated by tropical-subtropical conditions (Hallam 1982).

\section{Paleoredox proxies}

A selection of redox proxies, including $\mathrm{Mo}, \mathrm{U} / \mathrm{Th}, \mathrm{V} / \mathrm{Cr}, \mathrm{Ni} /$ $\mathrm{Co}$, and $\mathrm{V} /(\mathrm{V}+\mathrm{Ni}$ ) (Hatch and Leventhal 1992; Rimmer 2004; Deepulal et al. 2012; Ramos-Vázquez et al. 2017; Anaya-Gregorio et al. 2018; Armstrong-Altrin 2020; Armstrong-Altrin et al. 2019; Armstrong et al. 2020; AyalaPérez et al. 2021), as well as the TS-TOC relationship (Pearce

Table 2 Distribution of clay and non-clay minerals (in wt\%) in the solid bitumen and host shales of the Sargelu and Naokelekan Formations

\begin{tabular}{llllllll}
\hline Sample no. & Formation & Quartz (\%) & Dolomite/ankerite (\%) & Calcite (\%) & Alkali feldspar (\%) & Illite/muscovite (\%) & Pyrite (\%) \\
\hline 1 & Sargelu & 2.15 & 90.60 & 1.31 & 5.94 & - & - \\
2 & Sargelu & 17.63 & 63.14 & 4.20 & 15.03 & - & - \\
3 & Sargelu & 45.26 & 3.49 & 48.65 & 2.60 & - & - \\
4 & Sargelu & 13.19 & 31.32 & 38.11 & 17.38 & - & - \\
1 & Naokelekan & 2.68 & 36.60 & 45.37 & 15.35 & - & - \\
2 & Naokelekan & 2.70 & 2.00 & 87.94 & 6.05 & - & - \\
3 & Naokelekan & 3.61 & 1.84 & 85.73 & 6.88 & 51.16 & - \\
4 & Naokelekan & 21.40 & - & - & 5.30 & \\
\hline
\end{tabular}



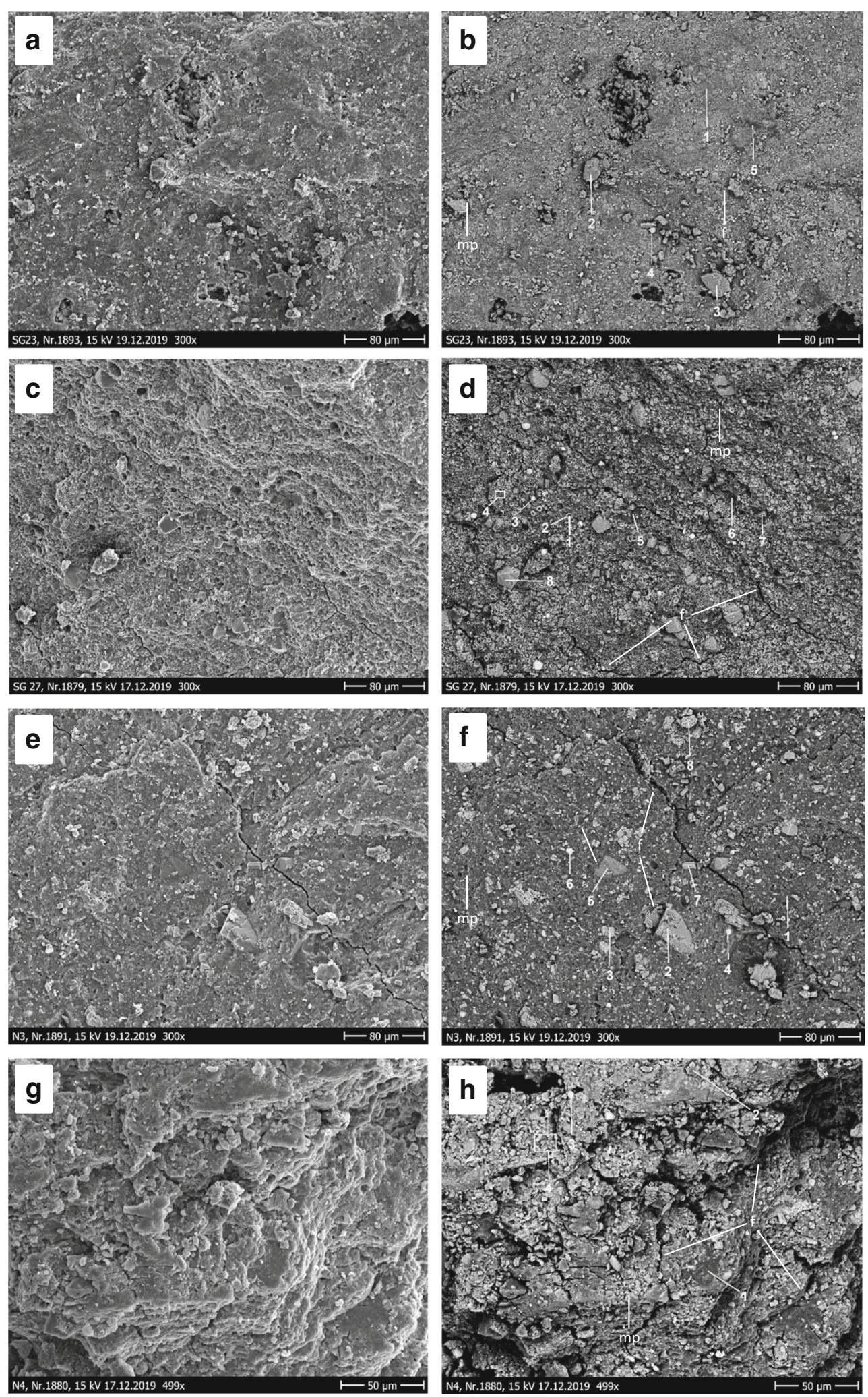

et al. 2010), were calculated from the solid bitumen and host shale samples (Fig. 7; Table 6).

The measured Mo values of the solid bitumen and host shale samples from the studied formations were very high, ranging from 111 to $662 \mathrm{ppm}$ in the Sargelu Formation and from 116 to $356 \mathrm{ppm}$ in the overlying Naokelekan Formation (Fig. 7; Table 6), strongly suggesting that deposition occurred under anoxic conditions, with conditions during the 
Fig. 6 SEM images of the Sargelu and Naokelekan Formations. (a) Topographic image of image (b). (b) Compositional contrast image with spotted areas. Spot 1: illite; spot 2: dolomite; spot 3: plagioclase feldspar; spot 4: illite; spot 5: pyrite framboid. (c) Topographic image of image (d). (d) Compositional contrast image with spotted areas. Spot 1: rectorite with organic matter (solid bitumen); spot 2: calcite with organic matter (solid bitumen); spot 3: pyrite framboid; spot 4: calcite with organic matter (solid bitumen); spot 5: organic matter (solid bitumen); spot 6: organic matter (solid bitumen); spot 7: kaolinite; spot 8: calcite with organic matter (solid bitumen). (e) Topographic image of image (f). (f) Compositional contrast image with spotted areas. Spot 1: organic matter (solid bitumen); spot 2: dolomite; spot 3: calcite; spot 4: pyrite framboid; spot 5: calcium phosphate with organic matter (solid bitumen); spot 6: pyrite framboid; spot 7: K-feldspar; spot 8: calcite. (g) Topographic image of image (h). (h) Compositional contrast image with spotted areas. Spot 1: pyrite framboid; spot 2: montmorillonite; spot 3: chlorite; spot 4: illite. f, fractures; $\mathrm{mp}$, micropores within all samples from both formations (Sargelu and Naokelekan); topographic image, secondary electron signal (low energy); compositional contrast image, back scattered electron signal (high energy) that shows bright and dark areas. The darker areas contain lighter elements, while the brighter areas contain heavier elements

deposition of the lowermost formation possibly being more anoxic (Francois 1988; Dean et al. 1997).

Jones and Manning (1994) suggested that the U/Th ratio can be used as a proxy indicator for redox conditions, where ratios of $>1.25$ are typical of anoxic deposition. Values of up to 67.6 were measured from the solid bitumen and host shale samples from the Sargelu Formation, while values up to 136.6 were measured from the solid bitumen and host shale samples from the Naokelekan Formation (Fig. 7; Table 6). These values suggest that both formations were deposited under anoxic conditions.

According to Hatch and Leventhal (1992) and Jones and Manning (1994), the ratio values of $\mathrm{V} / \mathrm{Cr}$ which are $<2$ indicate that the sediments were deposited within the oxic zone, while values $>4.25$ indicate that they were deposited within the suboxic to anoxic zone (Hatch and Leventhal 1992; Jones

Table 3 Total carbon, total inorganic carbon, and total organic carbon data for the samples of the Sargelu and Naokelekan Formations

\begin{tabular}{lllll}
\hline Sample no. & Formation & \% TC & \% TIC & \% TOC \\
\hline 1 & Sargelu & 15.97 & 8.5 & 7.5 \\
2 & Sargelu & 15.84 & 5.6 & 10.3 \\
3 & Sargelu & 10.00 & 5.7 & 4.3 \\
4 & Sargelu & 19.56 & 5.1 & 14.5 \\
Mean value & Sargelu & 15.34 & 6.23 & 9.15 \\
1 & Naokelekan & 24.73 & 5.9 & 18.8 \\
2 & Naokelekan & 32.30 & 6.4 & 25.9 \\
3 & Naokelekan & 31.04 & 6.1 & 24.9 \\
4 & Naokelekan & 48.09 & $<0.2$ & 48.1 \\
Mean value & Naokelekan & 34.24 & 4.65 & 29.43 \\
\hline
\end{tabular}

Table 4 TS and TOC relationship for the samples of the Sargelu and Naokelekan Formations

\begin{tabular}{llll}
\hline Sample no. & Formation & \% TOC & $\% \mathrm{TS}$ \\
\hline 1 & Sargelu & 7.5 & 0.85 \\
2 & Sargelu & 10.3 & 1.04 \\
3 & Sargelu & 4.3 & 0.54 \\
4 & Sargelu & 14.5 & 1.60 \\
1 & Naokelekan & 18.8 & 2.06 \\
2 & Naokelekan & 25.9 & 2.99 \\
3 & Naokelekan & 24.9 & 3.36 \\
4 & Naokelekan & 48.1 & 5.44 \\
\hline
\end{tabular}

and Manning 1994). The calculated V/Cr ratio values of the solid bitumen and host shale samples from the Sargelu Formation (5.39-7.43) fall within the suboxic to anoxic range. In comparison, the $\mathrm{V} / \mathrm{Cr}$ ratio values from the overlying Naokelekan Formation show a marked increase, ranging from 9.13 up to 14.99 . Such values are double some of those from the solid bitumen and host shale samples of the underlying Sargelu Formation. This might suggest that anoxia became more prevalent within the period during which the solid bitumen and host shales from the Naokelekan Formation were deposited (Fig. 7; Table 6).

Jones and Manning (1994) suggested that $\mathrm{Ni} / \mathrm{Co}$ ratio values of $<5$ indicate oxic conditions, while values of $>7$ would indicate suboxic to anoxic conditions. Indeed, high $\mathrm{Ni} / \mathrm{Co}$ ratio values are typical of reducing conditions where organic matter accumulates in the sediment (e.g., Raiswell and Plant 1980; Patterson et al. 1986). The Ni/Co values of the Naokelekan Formation (24.19-145.71) are noticeably higher than those recorded from the underlying Sargelu Formation (5.71-21.15), indicating that anoxia is considerably more prevalent within the Naokelekan Formation comparable to the Sargelu Formation, thus correlating well with the results obtained above (Fig. 7; Table 6).

Table 5 Carbon and oxygen isotope data for the solid bitumen and host shales from the Sargelu and Naokelekan Formations

\begin{tabular}{llll}
\hline Sample no. & Formation & $\delta^{13} \mathrm{C}$ & $\delta^{18} \mathrm{O}$ \\
\hline 1 & Sargelu & -2.58 & -3.75 \\
2 & Sargelu & -5.54 & -4.96 \\
3 & Sargelu & -7.10 & -5.24 \\
4 & Sargelu & -5.66 & -7.19 \\
1 & Naokelekan & -6.60 & -6.34 \\
2 & Naokelekan & -6.53 & -6.70 \\
3 & Naokelekan & -6.53 & -6.71 \\
4 & Naokelekan & - & - \\
\hline
\end{tabular}


Table 6 Trace (in ppm) element concentrations with paleoredox proxies: $\mathrm{Mo}, \mathrm{U} / \mathrm{Th}, \mathrm{V} / \mathrm{Cr}, \mathrm{Ni} / \mathrm{Co}$, $\mathrm{V} /(\mathrm{V}+\mathrm{Ni})$ for the solid bitumen and host shales of the MiddleLate Jurassic-age Sargelu and Naokelekan Formations

\begin{tabular}{|c|c|c|c|c|c|c|c|c|}
\hline \multirow[b]{2}{*}{ Element (ppm) } & \multicolumn{4}{|c|}{ Sargelu } & \multicolumn{4}{|c|}{ Naokelekan } \\
\hline & 1 & 2 & 3 & 4 & 1 & 2 & 3 & 4 \\
\hline $\mathrm{Sc}$ & $<\mathrm{DL}$ & 3 & $<\mathrm{DL}$ & $<\mathrm{DL}$ & $<\mathrm{DL}$ & $<\mathrm{DL}$ & $<\mathrm{DL}$ & 7 \\
\hline V & 316 & 519 & 130 & 383 & 564 & 675 & 1082 & 2823 \\
\hline $\mathrm{Cr}$ & 59 & 83 & 18 & 55 & 62 & 56 & 72 & 303 \\
\hline $\mathrm{Mn}$ & 61 & 70 & 21 & 60 & 58 & 23 & 26 & 20 \\
\hline Co & 13 & 36 & 22 & 15 & 11 & 3 & 5 & 4 \\
\hline $\mathrm{Ni}$ & 218 & 448 & 125 & 313 & 273 & 332 & 590 & 597 \\
\hline $\mathrm{Cu}$ & 90 & 134 & 15 & 60 & 55 & 35 & 35 & 87 \\
\hline $\mathrm{Zn}$ & 198 & 181 & 152 & 74 & 157 & 518 & 1165 & 524 \\
\hline $\mathrm{Ga}$ & 4 & 4 & $<\mathrm{DL}$ & 3 & 2 & 4 & 3 & 6 \\
\hline As & 47 & 68.1 & 13.8 & 41.3 & 36.3 & 25.7 & 27.2 & 77 \\
\hline $\mathrm{Rb}$ & 21 & 35 & 6 & 38 & 27 & 11 & 16 & 37 \\
\hline $\mathrm{Sr}$ & 81 & 98 & 150 & 124 & 140 & 289 & 298 & 94 \\
\hline Y & 16 & 29 & 11 & 36 & 42 & 26 & 29 & 85 \\
\hline $\mathrm{Zr}$ & 37 & 54 & 8 & 44 & 27 & 15 & 19 & 55 \\
\hline $\mathrm{Nb}$ & 4 & 5 & $<\mathrm{DL}$ & 4 & 4 & 2 & 3 & 6 \\
\hline Cs & 5 & 7 & 5 & 7 & 9 & 5 & 8 & 4 \\
\hline $\mathrm{Ba}$ & 104 & 113 & 22 & 82 & 124 & 230 & 158 & 366 \\
\hline $\mathrm{La}$ & 9 & 16 & 6 & 20 & 33 & 10 & 16 & 43 \\
\hline $\mathrm{Ce}$ & 23 & 26 & 13 & 19 & 12 & 18 & 1 & 20 \\
\hline $\mathrm{Nd}$ & 10 & 16 & 5 & 12 & 14 & 10 & 12 & 27 \\
\hline $\mathrm{Sm}$ & $<\mathrm{DL}$ & 2 & 4 & 7 & 2 & 3 & $<\mathrm{DL}$ & 7 \\
\hline Hf & $<\mathrm{DL}$ & $<\mathrm{DL}$ & $<\mathrm{DL}$ & $<\mathrm{DL}$ & $<\mathrm{DL}$ & $<\mathrm{DL}$ & $<\mathrm{DL}$ & $<\mathrm{DL}$ \\
\hline W & 25 & 43 & 144 & 25 & 29 & 9 & 10 & 15 \\
\hline $\mathrm{Pb}$ & 16 & 18 & 14 & 19 & 15 & 14 & 14 & 22 \\
\hline Th & $<\mathrm{DL}$ & $<\mathrm{DL}$ & $<\mathrm{DL}$ & 2 & $<\mathrm{DL}$ & $<\mathrm{DL}$ & $<\mathrm{DL}$ & $<\mathrm{DL}$ \\
\hline Mo & 275 & 662 & 111 & 177 & 116 & 356 & 299 & 311 \\
\hline $\mathrm{U}$ & 26.4 & 33.8 & 13.5 & 30.9 & 43.6 & 33.8 & 51.6 & 68.3 \\
\hline $\mathrm{U} / \mathrm{Th}$ & 52.8 & 67.6 & 27 & 15.45 & 87.2 & 67.6 & 103.2 & 136.6 \\
\hline $\mathrm{V} / \mathrm{Cr}$ & 5.39 & 6.23 & 7.43 & 7.02 & 9.13 & 11.98 & 14.99 & 9.33 \\
\hline $\mathrm{Ni} / \mathrm{Co}$ & 16.52 & 12.37 & 5.71 & 21.15 & 24.19 & 100.61 & 120.33 & 145.71 \\
\hline $\mathrm{V} /(\mathrm{V}+\mathrm{Ni})$ & 0.59 & 0.54 & 0.51 & 0.55 & 0.67 & 0.67 & 0.65 & 0.83 \\
\hline
\end{tabular}

The $\mathrm{V} /(\mathrm{V}+\mathrm{Ni})$ ratio is usually considered to be indicative of sediment deposition under euxinic conditions. According to Hatch and Leventhal (1992), V/(V + Ni) ratio values between 0.54 and 0.84 indicate anoxic conditions, while values greater than 0.84 would suggest euxinic conditions. The $\mathrm{V} /(\mathrm{V}+\mathrm{Ni})$ values of the solid bitumen and host shale samples from the Sargelu Formation (i.e., 0.54-0.59) would possibly suggest that the solid bitumen and host shales of the Sargelu Formation were deposited under anoxic conditions (with the exception for one sample which has a value of c. 0.51$)$. The $\mathrm{V} /(\mathrm{V}+\mathrm{Ni})$ values of the solid bitumen and host shales from the overlying Naokelekan Formation increase from. 0.65 to 0.83 . Such values would suggest that anoxia became more prevalent within the period of deposition of the solid bitumen and host shales of the Naokelekan Formation, again confirming the results obtained from the above analyses (Fig. 7; Table 6).

The TS-TOC relationship could be also indicative of reducing conditions (cf. Pearce et al. 2010). There is an overall increase in TS content (e.g., 1.04, 1.60, 2.06, 2.99) within the samples from the Sargelu and Naokelekan Formations with a corresponding increase in TOC content (e.g., 10.3, $14.5,18.8,25.9)$, except for one sample from the Naokelekan Formation which has a considerably higher value of TS (5.44) and a higher value of TOC (48.1) (see Table 4). This positive relationship between the TS and TOC contents is indicative of syngenetic pyrite formation under reducing conditions (Pearce et al. 2010).

According to Liu et al. (2019), pyrites can be subdivided, based on the formation mechanism, into syngenetic pyrites, 


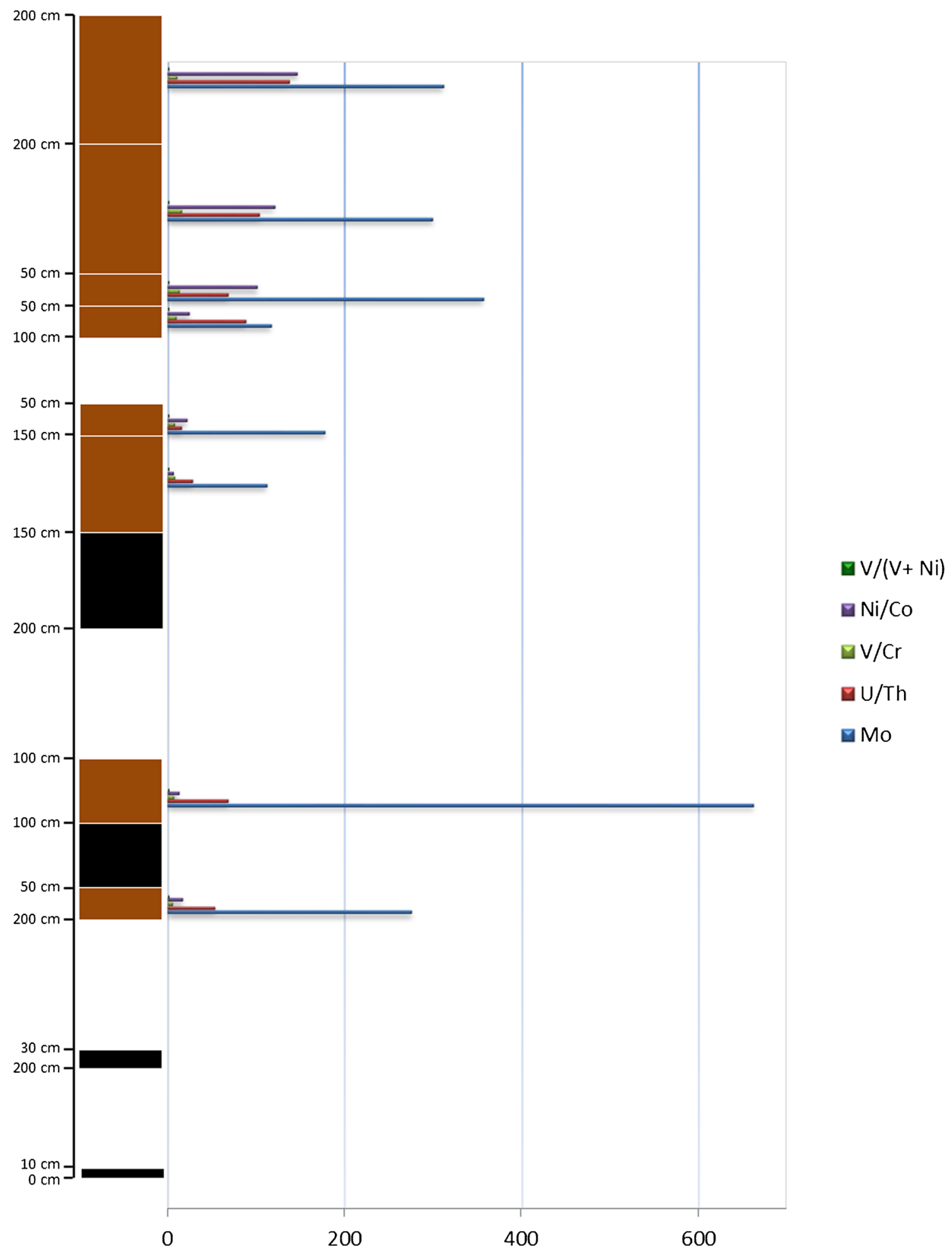

Fig. 7 The host shales and solid bitumen of the Sargelu and Naokelekan Formations, from the measured log of the Banik section, northernmost Iraq, showing geochemical proxies for paleoredox conditions. White-

colored beds, carbonate; black-colored beds, shale; dark brown-colored beds, shale hosting solid bitumen

early diagenetic pyrites, and late diagenetic pyrites. SEM and EDX analysis revealed the presence of syngenetic pyrites within all of the solid bitumen and host shale samples from the Sargelu and Naokelekan Formations (Fig. 6b, d, f, h;

Supplementary Fig. 1e, h, q, s, v). The observed syngenetic pyrites are mostly small framboids composed of microcrystals. According to Wilkin et al. (1996) and Gallego-Torres et al. (2015), the size distribution of pyrite framboids is 
indicative of anoxic-euxinic environments in ancient marine sediments. As noted, the majority of the syngenetic pyrites from the Banik area are small framboids (i.e., smaller than 5 $\mu \mathrm{m})$ suggesting that euxinic conditions were predominant during the time of deposition of the Sargelu and Naokelekan Formations (cf. Liu et al. 2019). Interestingly, a recent study (Abdula et al. 2020) on Rock-Eval analysis and organic petrographical characterization of the Upper Jurassic Naokelekan Formation from the Northern Mesopotamian Basin in Iraqi Kurdistan suggests that the co-occurrence of bituminite with pyrite framboids is indicative of reducing (anoxic to euxinic) conditions during the time of the deposition of the Naokelekan Formation sediments.

The various geochemical proxies discussed above would all suggest that the solid bitumen and host shale from both the Sargelu and Naokelekan Formations were deposited under reducing (anoxic to euxinic) conditions. Furthermore, it appears that the Naokelekan Formation was deposited during a period of more marked anoxia. Given that both formations were deposited in a shallow-marine shelf setting which would most likely be oxic, we need to explain the very clear anoxia signal which has been revealed from the geochemical proxies. Tyson (1989) and Tyson and Pearson (1991) have outlined a number of factors which can be used to determine the occurrence of dysoxic/anoxic facies in shelf settings, including high TOC contents (3-60\%), absence (or low diversity) of benthos, general absence of coarse clastics, and association with warmer paleoclimates. These factors can be related to basin stratification, impingement and penetration of the expanded Oxygen Minimum Zone, and upwelling models and models related to changes in sea level and/or sea bottom topography as well as fluvial influence (e.g., Van der Zwaan and Jorissen 1991). It is difficult to determine the precise importance of the first three of these, so we will concentrate on the latter controls.

As noted above, the TOC contents of the Sargelu and Naokelekan Formations range from 4.3 to $48.1 \%$. Additionally, the benthos, as reported by Omar et al. (2020), comprise only rare ostracods (Loricoecia loricate). Furthermore, the formations are dominated by mudstones, and a marked absence of coarser clastics, with deposition occurring during a warm period. These observations support the fact that the deposition of the Sargelu and Naokelekan Formations possibly occurred under low oxygen conditions (Tyson 1989). Many authors noted that rising sea level can lead to an increase in anoxia in shelf settings (Gertsch et al. 2010; Danise et al. 2013). While, the period of deposition of the Middle and Upper Jurassic formations corresponded to that of a broad eustatic transgression (Buday 1980; Haq 2018), resulting in higher global sea levels (Hallam 1982; Alsharhan and Nairn 2003). The situation, however, in Northern Iraq in Jurassic times was very different, since the environment was a shallow-marine setting at the time of deposition.
Omar et al. (2020) have interpreted the disparity in terms of the rising sea level and the shallow-marine depositional environment of the Sargelu and Naokelekan Formations in northernmost Iraq as being related to Cimmerian-related uplift tectonic activity (see also Buday 1980) which may have modified the sea level rise due to the formation of small restricted subbasins. Tobia et al. (2019) have examined the sediments of the Sargelu and Naokelekan Formations from Iraqi Kurdistan and determined that they were deposited in an anoxic deep-marine setting (with the exception of the lowermost Sargelu Formation sediments which show evidence of oxic shallow-marine setting). These results do not agree with the findings from the current study, apart from the clear anoxic signature which is present within the bulk of the Sargelu and Naokelekan Formations' sediments. The unequivocal shallow-marine signature derived from the isotopes clearly does not allow a deep-marine setting for the anoxia to be determined. Based on the factors outlined above by Tyson (1989) and Tyson and Pearson (1991), it is clear that the sediments of the Sargelu and Naokelekan Formations show a definitive anoxic signature. As noted above, the depositional setting was shallow marine; the region was also one which was tectonically active with the NE (which includes the Banik area) and $\mathrm{N}$ boundaries of the Arabian Plate representing the area of collision with the Cimmerian plates (Jassim and Goff 2006). Subsequent to this collision, a period of uplift (i.e., Cimmerian uplift; Buday 1980) occurred, possibly resulting in the subdivision of the depositional setting as a result of tectonic deformation (i.e., subbasin formation, basin compartmentalization; Omar et al. 2020). This tectonic fragmentation of the marine shelf into areas of higher and lower relief was similar, in some ways, to the Cretaceous-age Northern Calcareous Alps (Austria), where the depositional setting was compartmentalized as a result of deformation (Sanders 1998). Such compartmentalization (Pratt et al. 2008) would have resulted in marked differences between various subbasins, and-we would herein suggest - the development of anoxic facies within some of these subbasins. Thus, our explanation, invoking tectonic deformation resulting in the formation of subbasins with restricted circulation, would appear to be the best current explanation for this dilemma.

\section{Vitrinite reflectance}

The equivalent vitrinite reflectance value was determined for the eight samples from the Sargelu and Naokelekan Formations using three standard equations, which are as follows: Jacob (1989) equation: Ro eq. vitrinite $=0.618 \mathrm{RB}+$ 0.40 , Riediger (1993) equation: Ro eq. vitrinite $=0.277 \mathrm{RB}+$ 0.57 , Schoenherr et al. (2007) equation: Ro eq. vitrinite $=(R B$ $+0.2443) / 1.0495$. The equivalent vitrinite reflectance value is used to decipher the origin of the solid bitumen accumulated within the studied shale beds, determining whether the solid bitumen was initially oil, generated from the same shale beds, 
or if it was generated elsewhere and subsequently migrated. The equivalent vitrinite reflectance values obtained from the Sargelu and Naokelekan samples are all broadly similar (Table 7). The shale containing the solid bitumen has very low equivalent vitrinite reflectance values, suggesting that the shale is not the source rocks for the solid bitumen.

Integrating the geochemical data with the equivalent vitrinite reflectance values from the studied shale allow us to reconstruct the accumulation process for the solid bitumen. During Middle and Late Jurassic times, oil migrated into the Sargelu and Naokelekan Formations. The reservoir rocks provided ideal conditions for trapping the petroleum, which was subsequently transformed into solid bitumen. Thus, the bitumen is a secondary product, and not related to the primary depositional conditions. The source of the petroleum, however, is unclear-but one possible source would be the carbonates which are interbedded with the studied shale, since the Jurassic marine carbonates are the major sources of hydrocarbons produced in the Zagros Basin (Al-Ahmed 2006) which include the Middle to Upper Jurassic Sargelu and Naokelekan Formations in Iraq.

\section{Mineral content}

As noted above, the shales within the two studied formations are the host rock for the solid bitumen which formed elsewhere and migrated into that shale where it crystallized. Examining the mineral content of the shales allows us to determine the degree to which these shale rocks provide good reservoir quality. The studied carbonate-rich shale has a heterogeneous composition as recorded in their mineralogy (Figs. 5 and 6; Table 2).

In the present work, the shale is commonly carbonate-rich including calcite and Fe-rich dolomite (ankerite); the amount of calcite ranges from 45.3 to $87.9 \%$ in the Naokelekan Formation while the amount of ankerite can be up to $90 \%$ in the Sargelu Formation (Table 2). The generation of micropores and fractures as a result of the presence of highly soluble carbonate minerals such as calcite and dolomite, in addition to tectonically related fracturing, enhanced the storage capacity of the studied shale. Indeed, the presence of dissolution-related micropores was confirmed by SEM analysis which also revealed the presence of fractures in the studied shales (Fig. 6b, d, f, h). These micropores and fractures, acting as migration or flow conduits, would have enhanced the ability of the studied shales to act as a reservoir for the migrating bitumen.

The carbonates are, in general, better reservoir rocks. Additionally, as noted above, the carbonates which are interbedded with the shale have been regarded as one possible source of hydrocarbons for the Middle to Upper Jurassic Sargelu and Naokelekan Formations. However, the carbonate rocks of the two studied formations are not considered to be of reservoir quality. Aqrawi et al. (2010) have noted that porous Middle to Late Jurassic-age limestone reservoirs, analogous to the Arab Formation of Saudi Arabia, have not yet been described from Iraq. The Middle to Upper Jurassic source rocks in Iraq are typically condensed carbonate-rich intervals containing high-quality, organic-rich hydrocarbons and deposited under deep marine, restricted basinal conditions (Aqrawi et al. 2010).

Omar et al. (2020) have noted that the precursor limestones of the Sargelu Formation were wholly or partly converted to dolomite rock. The presence of extensive and pervasive dolomite has resulted in the formation of tight carbonate rocks so less dissolution may have occurred. The secondary porosity, which formed as a result of the dissolution of fossils, was thus filled with later calcite and dolomite cements effectively reducing porosity. The matrix permeability is similar to the porosity filled by calcite and dolomite cements, which limited any enhancement of the fluid flow by fractures, resulting in a situation where the only pathways or conduits for fluid flow were the partially filled calcite fractures and intercrystalline pores. Consequently, both the porosity and the permeability were extremely restricted, and the only available porosity was in the shales.
Table 7 The equivalent vitrinite reflectance values using different equations

\begin{tabular}{lllll}
\hline Sample no. & Formation & *Ro eq. vitrinite $(\%)$ & $* *$ Ro eq. vitrinite $(\%)$ & $* * *$ Ro eq. vitrinite (\%) \\
\hline 1 & Sargelu & 0.68 & 0.69 & 0.66 \\
2 & Sargelu & 0.73 & 0.72 & 0.75 \\
3 & Sargelu & 0.72 & 0.71 & 0.73 \\
4 & Sargelu & 0.81 & 0.75 & 0.86 \\
1 & Naokelekan & 0.76 & 0.73 & 0.79 \\
2 & Naokelekan & 0.73 & 0.72 & 0.75 \\
3 & Naokelekan & 0.73 & 0.72 & 0.75 \\
4 & Naokelekan & 0.72 & 0.71 & 0.72 \\
\hline
\end{tabular}

$*$ Jacob (1989) equation: Ro eq. vitrinite $=0.618 \mathrm{RB}+0.40$

$* *$ Riediger (1993) equation: Ro eq. vitrinite $=0.277 \mathrm{RB}+0.57$

$* * *$ Schoenherr et al. (2007) equation: Ro eq. vitrinite $=(\mathrm{RB}+0.2443) / 1.0495$ 


\section{Conclusions}

The solid bitumen preserved within the shales of the Middle and Upper Jurassic succession of the Banik section from northernmost Iraq was accumulated in the Sargelu and Naokelekan Formations. The accumulation process took place within the host shale. Petrographical, mineralogical, organic, and inorganic geochemical studies have been carried out on the reservoir rocks and solid bitumen. The Banik section is dominated by dolomites, limestones, and shales. Accumulation of the solid bitumen in the host shales of the area is interpreted to have occurred, probably as a result of oil migration from other source rocks within the same formations. In terms of the geological setting, the Jurassic succession was dominated by organic-rich source rocks and highly porous and permeable reservoir rocks. Together, the results in this study would suggest that source rocks, during the Jurassic time, reached a peak for petroleum generation. Meanwhile, under the influence of the ongoing tectonic activity in the region of northernmost Iraqi Kurdistan, the occurrence of fractures and faults provided effective pathways for oil migration from the source rocks through the porous and permeable reservoir rocks (i.e., host shales) in the stratigraphic succession of the Banik section.

Additionally, the results from the carbon and oxygen isotope data and the paleoredox proxies in this study would suggest that the host shale and solid bitumen sources within the Middle-Late Jurassic-age Sargelu and Naokelekan Formations were deposited in a shallow-marine setting and under anoxic conditions.

Supplementary Information The online version contains supplementary material available at https://doi.org/10.1007/s12517-021-07048-9.

Acknowledgements We would like to thank, particularly, Hans-Jürgen Ensikat for initiating and supporting the scanning electron microscopy (SEM) and energy-dispersive X-ray microanalysis (EDX). Finally, we thank our reviewers for their thorough reviews of the manuscript.

Funding Open Access funding enabled and organized by Projekt DEAL. This study is supported by the Arab-German Young Academy of Sciences and Humanities (AGYA) grants (AGYA_2020_AP_01).

\section{Declarations}

Conflict of interest The authors declare that they have no competing interests.

Open Access This article is licensed under a Creative Commons Attribution 4.0 International License, which permits use, sharing, adaptation, distribution and reproduction in any medium or format, as long as you give appropriate credit to the original author(s) and the source, provide a link to the Creative Commons licence, and indicate if changes were made. The images or other third party material in this article are included in the article's Creative Commons licence, unless indicated otherwise in a credit line to the material. If material is not included in the article's Creative Commons licence and your intended use is not permitted by statutory regulation or exceeds the permitted use, you will need to obtain permission directly from the copyright holder. To view a copy of this licence, visit http://creativecommons.org/licenses/by/4.0/.

\section{References}

Abdula R (2017) Source rock assessment of Naokelekan formation in Iraqi Kurdistan. JZS-A 19:103-124

Abdula RA, Balaky SM, Nourmohamadi MS, Piroui M (2015) Microfacies analysis and depositional environment of the Sargelu Formation (Middle Jurassic) from Kurdistan Region, Northern Iraq. Donnish J Geol Min Res 1:1-26

Abdula RA, Kolo K, Damoulianou M, Raftopoulou V, Khanaqa P, Kalaitzidis S (2020) Rock-Eval analysis and organic petrographical characterization of the Upper Jurassic Naokelekan Formation, Northern Mesopotamian Basin, Kurdistan Region-Iraq. BGSG 187-203

Ahlbrandt TS, Pollastro RM, Klett TR, Schenk CJ, Lindquist SJ, Fox JE (2000) Region 2 assessment summary-Middle East and North Africa. In USGS World Petroleum Assessment 2000-Description and Results, Chapter R2: DDS-60, pp 46

Akkoca DB, Işık Ü (2018) Geochemistry of Paleozoic Dadaș shales from the foreland of southeastern Turkey, Bismil, Diyarbakır. Period di Mineral 87:199-217

Al-Ahmed AAN (2006) Organic geochemistry, palynofacies and hydrocarbon potential of Sargelu Formation (Middle Jurassic) northern Iraq. $\mathrm{PhD}$ thesis, University of Baghdad, Iraq

Al-Ameri TK, Zumberge J (2012) Middle and Upper Jurassic hydrocarbon potential of the Zagros Fold Belt, North Iraq. Mar Pet Geol 36: 13-34

Al-Ameri TK, Al-Jubouri NM, Isa MJ, Al-Azzawi RE (2012) Hydrocarbons generation potential of the Jurassic-Lower Cretaceous Formation, Ajeel field, Iraq. Arab J Geosci 6:3725-3735

Al-Juboury AI, McCann T (2013) Petrological and geochemical interpretation of Triassic-Jurassic boundary sections from North Iraq. Geol J $50: 157-172$

Al-Mousawi HA, Sissakian VK, Fouad SF, Survey IG (2008) The geology of Zakho Quadrangle, Scale 1:250000. Baghdad, Iraq, Iraq Geological Survey

Alsharhan AS, Nairn AEM (2003) Sedimentary basins and petroleum geology of the Middle East. Netherlands, Elsevier Science, Amsterdam, $843 \mathrm{pp}$

Altinli IE (1966) Geology of eastern and southeastern Anatolia, Turkey, pp. 35-76. Bulletin of Mineral Research Exploration Institute of Turkey, Foreign Edition, Ankara no. 60.

Al-Zubaidi AA, Al-Zebari AY (1998) Prospects for production and marketing of Iraq's heavy oil: ministry of oil. State Oil Marketing, Baghdad, Iraq, 221, pp 10

Anaya-Gregorio A, Armstrong-Altrin JS, Machain-Castillo ML, MontielGarcia PC, Ramos-Vazquez MA (2018) Textural and geochemical characteristics of late Pleistocene to Holocene fine-grained deep-sea sediment cores (GM6 and GM7), recovered from the southwestern Gulf of Mexico. J Paleogeo 7:1-19

Aqrawi AAM (1998) Paleozoic stratigraphy and petroleum systems of the western and southwestern Deserts of Iraq. GeoArabia 3:229-247

Aqrawi AAM, Badics B (2015) Geochemical characterisation, volumetric assessment and shale-oil/gas potential of the Middle JurassicLower Cretaceous source rocks of NE Arabian Plate. GeoArabia 20: 99-140

Aqrawi AAM, Goff JC, Horbury AD, Sadooni FN (2010) The petroleum geology of Iraq. Scientific Press, pp 424 
Armstrong-Altrin JS, Ramos-Vázquez MA, Hermenegildo-Ruiz NY, Madhavaraju J (2020) Microtexture and U-Pb geochronology of detrital zircon grains in the Chachalacas Beach, Veracruz State, Gulf of Mexico. Geol J 3:1-12. https://doi.org/10.1002/gj.3984

Armstrong-Altrin JS (2020) Detrital zircon U-Pb geochronology and geochemistry of the Riachuelos and Palma Sola beach sediments, Veracruz State, Gulf of Mexico: a new insight on palaeoenvironment. J Palaeogeogr 9:28. https://doi.org/10.1186/ s42501-020-00075-9

Armstrong-Altrin JS, Botello AV, Villanueva SF, Soto LA (2019) Geochemistry of surface sediments from the northwestern Gulf of Mexico: implications for provenance and heavy metal contamination. Geol Quart 63(3):522-538

Awdal A, Healy D, Alsop GI (2016) Fracture patterns and petrophysical properties of carbonates undergoing regional folding: a case study from Kurdistan, N Iraq. Mar Pet Geol 71:149-167

Ayala-Pérez MP, Armstrong-Altrin JS, Machain-Castillo ML (2021) Heavy metal contamination and provenance of sediments recovered at the Grijalva River delta, southern Gulf of Mexico. J Earth Syst Sci. https://doi.org/10.1007/s12040-021-01570-w

Balaky SM, Swrdashy AM, Mamaseni WJ (2016) Permian-Triassic lithostratigraphic study in the Northern Thrust Zone (Ora), Iraqi Kurdistan region. Arab J Geosci 9:343

Bartolini A, Pittet B, Mattioli E, Hanziker JC (2003) Shallow-platform palaeoenvironmental conditions recorded in deep-shelf sediments: $\mathrm{C}$ and $\mathrm{O}$ stable isotopes in Upper Jurassic sections of southern Germany (Oxfordian - Kimmeridgian). Sediment Geol 160:107130

Bellen RCV, Dunnington HV, Wetzel R, Morton DM (1959) Lexique Stratigraphique International, vol III. Paris: Asie, Fascicule 10a Iraq, pp 333

Bennett WW, Canfield DE (2020) Redox-sensitive trace metals as paleoredox proxies: a review and analysis of data from modern sediments. Earth-Sci Rev 204:103175

Beydoun ZR (1991) Arabian plate hydrocarbon geology and potential. A plate tectonic approach AAPG 33:1-77

Bowman AR, Bralower TJ (2005) Paleoceanographic significance of high-resolution carbon isotope records across the CenomanianTuronian boundary in the Western Interior and New Jersey coastal plain, USA. Mar Geol 217:305-321

Buday T (1980) The regional geology of Iraq. Stratigraphy and palaeogeography. Publication of GEOSURV, vol. 1. Baghdad, $p$ 445

Danise S, Twitchett RJ, Little CTS, Clémence ME (2013) The impact of global warming and anoxia on marine benthic community dynamics: an example from the Toarcian (Early Jurassic). PLoS One 8: e56255

Daoud HS, Karim KH (2010) Types of stromatolites in the Barsarin Formation (late Jurassic), Barzinja area, NE Iraq. Iraqi Bull Geol Mining 6:47-57

Dean WE, Gardner JV, Piper DZ (1997) Inorganic geochemical indicators of glacial - interglacial changes in productivity and anoxia on the California continental margin. Geochim Cosmochim Acta 61: $4507-4518$

Deepulal PM, Gireesh Kumar TR, Sujatha CH, George R (2012) Chemometric study on the trace metal accumulation in the sediments of the Cochin Estuary-Southwest coast of India. Environ Monit Assess 184:6261-6279

Dubertret B (1966) Liban, Syrie et bordure des pays voisins: Notes and Memoires Meyen Orient, vol. VIII. Paris.

Edilbi ANF, Maleko MA, Mohamed AY (2017) Evaluating the Baluti Formation at Sararu village, Ora Anticline, Iraqi Kurdistan: a stratigraphic and geochemical approach. Arab J Geosci 10:73

El Diasty WS, El Beialy SY, Peters KE, Batten DJ, Al-Beyati FM, Mahdi AQ, Hasseb MT (2018) Organic geochemistry of the Middle-Late
Jurassic Naokelekan Formation in the Ajil and Balad oil fields, northern Iraq. J Pet Sci Eng 166:350-362

Francois R (1988) A study on the regulation of the concentrations of some trace elements ( $\mathrm{Rb}, \mathrm{Sr}, \mathrm{Zn}, \mathrm{Pb}, \mathrm{Cu}, \mathrm{V}, \mathrm{Cr}, \mathrm{Ni}, \mathrm{Mn}$ and $\mathrm{Mo})$ in Saanich Inlet sediments, British Columbia, Canada. Mar Geol 83: 285-308

Gallego-Torres D, Reolid M, Nieto-Moreno V, Martínez-Casado FJ (2015) Pyrite framboid size distribution as a record for relative variations in sedimentation rate: an example on the Toarcian oceanic anoxic event in South Iberian palaeomargin. Sediment Geol 330:59 73

Gertsch B, Adatte T, Keller G, Tantawy AAAM, Berner Z, Mort HP, Fleitmann D (2010) Middle and late Cenomanian oceanic anoxic events in shallow and deeper shelf environments of western Morocco. Sedimentology 57:1430-1462

Hallam A (1982) The Jurassic climate. In Climate in Earth history: studies in geophysics, pp. 159-163. The National Academies Press. https:// doi.org/10.17226/11798.

Haq BU (2018) Jurassic sea-level variations: a reappraisal. GSA Today 28:4-10

Hatch JR, Leventhal JS (1992) Relationship between inferred redox potential of the depositional environment and geochemistry of the Upper Pennsylvanian (Missourian) Stark Shale Member of the Dennis Limestone, Wabaunsee County, Kansas, USA. Chem Geol 99:65-82

Jacob H (1989) Classification, structure, genesis and practical importance of natural solid oil bitumen ("migrabitumen"). Int J Coal Geol 11: 65-79

James GA, Wynd JG (1965) Stratigraphic nomenclature of Iranian oil consortium agreement area. AAPG Bull 49:2182-2245

Jarvis I, Gale AS, Jenkyns HC, Pearce MA (2006) Secular variation in Late Cretaceous carbon isotopes: a new $\delta 13 \mathrm{C}$ carbonate reference curve for the Cenomanian-Campanian (99.670.6 Ma). Geol Mag 143:561-608

Jasim SY (2013) The potential of hydrocarbons generation in the Chia Gara Formation at Amadia area, north of Iraq. Arab J Geosci 6: 3313-3318

Jassim SZ, Al-Gailani M (2006) Hydrocarbons. In: Jassim SZ, Goff JC (eds) Geology of Iraq. Dolin; Brno: Moravian Museum, Prague, pp 232-250

Jassim SZ, Buday T (2006) Late Toarcian-Early Tithonian (Mid-Late Jurassic) megasequence AP7. In: Jassim SZ, Goff JC (eds) Geology of Iraq. Dolin; Brno: Moravian Museum, Prague, pp $117-123$

Jassim SZ, Goff J (2006) Geology of Iraq. Dolin; Brno: Moravian Museum, Prague, $318 \mathrm{p}$

Jones B, Manning DAC (1994) Comparison of geochemical indices used for the interpretation of palaeoredox conditions in ancient mudstones. Chem Geol 111:111-129

Liu X, Wen Z, Wang Z, Song C, He Z (2018) Structural characteristics and main controlling factors on petroleum accumulation in Zagros Basin, Middle East. J Nat Gas Geosci 5:273-281

Liu Z, Chen D, Zhang J, Lü X, Wang Z, Liao W, Shi X, Tang J, Xie G (2019) Pyrite morphology as an indicator of paleoredox conditions and shale gas content of the Longmaxi and Wufeng Shales in the Middle Yangtze Area, South China. Minerals 9:428

Mohialdeen IMJ, Hakimi MH, Al-Beyati FM (2013) Geochemical and petrographic characterisation of Late Jurassic-Early Cretaceous Chia Gara Formation in Northern Iraq: palaeoenvironment and oilgeneration potential. Mar Pet Geol 43:166-177

Murris RJ (1980) Middle East: stratigraphic evolution and oil habitat. AAPG Bull 64:597-618

Numan NMS (2000) Major cretaceous tectonic events in Iraq. Raf J Sci 11:32-52

Omar N, McCann T, Al-Juboury AI, Franz SO (2020) Petrography and geochemistry of the Middle-Upper Jurassic Banik section, 
northernmost Iraq - implications for palaeoredox, evaporitic and diagenetic conditions. N Jb Geol Palaeont Abh 297:125-152

Patterson JH, Ramsden AR, Dale LS, Fardy JJ (1986) Geochemistry and mineralogical residences of trace elements in oil shales from Julia Creek, Queens- land, Australia. Chem Geol 55:1-16

Pearce CR, Coe AL, Cohen AS (2010) Seawater redox variations during the deposition of the Kimmeridge Clay Formation, United Kingdom (Upper Jurassic): evidence from molybdenum isotopes and trace metal ratios. Paleoceanography 25:PA4213

Pitman JK, Steinshouer D, Lewan MD (2004) Petroleum generation and migration in the Mesopotamian Basin and Zagros Fold Belt of Iraq: results from a basin-modeling study. GeoArabia 9:41-72

Pratt JR, Schoenbohm LA, Mortimer E, Schmitt A (2008) Basin Compartmentalization in the Sierra Pampeanas of Northwestern Argentina: case-study of the El Cajón Basin. Senior thesis, The Ohio State University, USA. Published thesis. https://kb.osu.edu/ handle/1811/57007

Raiswell R, Plant J (1980) The incorporation of trace elements into pyrite during diagenesis of black shales, Yorkshire, England. Econ Geol 75:684-699

Ramos-Vázquez MA, Armstrong-Altrin JS (2019) Sediment chemistry and detrital zircon record in the Bosque and Paseo del Mar coastal areas from the southwestern Gulf of Mexico. Mar Pet Geol 110: $650-675$

Ramos-Vázquez MA, Armstrong-Altrin JS, Rosales-Hoz L, MachainCastillo ML, Carranza-Edwards A (2017) Geochemistry of deepsea sediments in two cores retrieved at the mouth of the Coatzacoalcos River delta, western Gulf of Mexico, Mexico. Arab J Geosci 10:1-19

Riediger CL (1993) Solid bitumen reflectance and Rock-Eval Tmax as maturation indices: an example from the "Nordegg Member", Western Canada Sedimentary Basin. Int J Coal Geol 22:295-315

Rimmer SM (2004) Geochemical paleoredox indicators in DevonianMississippian black shales, Central Appalachian Basin (USA). Chem Geol 206:273-391

Ruf M, Link E, Pross J, Aigner T (2005) integrated sequence stratigraphy: Facies, stable isotope, and palynofacies analysis in a deeper epicontinental carbonate ramp (Late Jurassic, SW Germany). Sediment Geol 175:391-414

Sanders D (1998) Tectonically controlled Late Cretaceous terrestrial to neritic deposition (Northern Calcareous Alps, Tyrol, Austria). Facies 39:139-178

Sarfi M, Ghasemi-Nejad E, Mahanipour A, Yazdi-Moghadam M, Sharifi M (2015) Integrated biostratigraphy and geochemistry of the lower
Cretaceous Radiolarian Flood Zone of the base of the Garau Formation, northwest of Zagros Mountains, Iran. Arab J Geosci 8: 7245-7255

Schoenherr J, Littke R, Urai JL, Kukla PA, Rawahi Z (2007) Polyphase thermal evolution in the Infra-Cambrian Ara Group (South Oman Salt Basin) as deduced by maturity of solid reservoir bitumen. Org Geochem 38:1293-1318

Sharland PR, Archer R, Casey DM, Davies RB, Hall SH, Heward AP, Horbury AD, Simmons MD (2001) Arabian plate sequence stratigraphy. GeoArabia, Special Publication no. 2, Gulf PetroLink, Bahrain, pp 371

Tobia FH, Al-Jaleel HS, Ahmad IN (2019) Provenance and depositional environment of the Middle-Late Jurassic shales, northern Iraq. Geosci J 23:747-765

Tyson RV (1989) Source rock palaeoenvironments: principles, models, and mid-Cretaceous patterns. Unpublished Report for Masera Corporation, Tulsa

Tyson RV, Pearson TH (1991) Modern and ancient continental shelf anoxia: an overview. In Modern and Ancient continental shelf anoxia (eds. RV Tyson and TH Pearson). Geol Soc Spec Publ 58:1-24

Van der Zwaan GJ, Jorissen FJ (1991) Biofacial patterns in river-induced shelf anoxia. In Modern and ancient continental shelf anoxia (eds. RV Tyson and TH Pearson). Geol Soc Spec Publ 58:65-82

Verma MK, Ahlbrandt TS, Al Gailani M (2004) Petroleum reserves and undiscovered resources in the total petroleum systems of Iraq: reserve growth and production implications. GeoArabia 9:51-74

Weissert H, Erba E (2004) Volcanism $\mathrm{CO}_{2}$ and paleoclimate: a late Jurassic - Early Cretaceous carbon and oxygen isotopes record. J Geol Soc Lond 161:695-702

Wetzel R (1948) Sargelu Formation. In: Bellen RCV, Dunnington HV, Wetzel R, Morton DM (eds) Lexique stratigraphique international, vol III. Asie, Fascicule 10a Iraq, Paris, pp 250-253

Wetzel R, Morton DM (1950) Sehkaniyan Formation. In: Bellen RCV, Dunnington HV, Wetzel R, Morton DM (eds) Lexique stratigraphique international, vol III. Asie, Fascicule 10a Iraq, Paris, pp 211-215

Wilkin RT, Barnes HL, Brantley SL (1996) The size distribution of framboidal pyrite in modern sediments: an indicator of redox conditions. Geochim Cosmochim Acta 60:3897-3912

Zainy MT, Al-Ansari N, Bauer TE, Ask M (2017) The tectonic and structural classifications of the Western part of the Zagros Fold and Thrust Belt, North Iraq, review and discussion. J Earth Sci Geotech Eng 7:71-89 